\title{
From Selling Goods to Selling Services: Firm Responses to Trade Liberalization*
}

\author{
Holger Breinlich†, Anson Soderbery ${ }^{\ddagger}$ and Greg C. Wright ${ }^{\S}$
}

December 12, 2017

\begin{abstract}
In this paper we focus on a new channel of adaptation to trade liberalization, namely the shift toward increased provision of services in lieu of goods production. We exploit variation in European Union trade policy to show that lower manufacturing tariffs lead firms to shift into services provision and out of goods production. We also find that a successful transition is associated with higher firm-level R\&D stocks.
\end{abstract}

Key Words: Services Trade, Trade Liberalization, Import Competition

JEL Codes: F12, F15, F23

*This work contains statistical data from the Office for National Statistics (ONS) which is Crown copyright and reproduced with the permission of the controller of HMSO and Queen's Printer for Scotland. The use of the ONS' statistical data in this work does not imply endorsement of the ONS in relation to the interpretation or analysis of the statistical data. This work uses research datasets which may not exactly reproduce National Statistics aggregates. We thank the editor and two anonymous referees as well as conference participants at the ETSG Conference 2013 and the EIST Conference Ankara. We also thank seminar participants at the University of Southern Denmark, the University of Oxford and the London School of Economics for helpful comments and suggestions. All remaining errors are our own.

${ }^{\dagger}$ Breinlich: University of Nottingham, CEP and CEPR, University Park, Nottingham, NG7 2RD, U.K.

${ }^{\ddagger}$ Soderbery: Purdue University, West Lafayette, IN 47907-2056.

$\S$ Wright: University of California, Merced, 5200 N. Lake Rd., Merced, 95343 


\section{Introduction}

Domestic firms respond to trade liberalization in a number of ways. As import tariffs fall, some firms shrink and eventually exit their market altogether, whereas others adapt and survive. Those who survive do so in several ways. Recent work has shown that firms respond by increasing their innovation efforts (Bloom, Draca and Van Reenen, 2016; Teshima, 2010), by increasing the quality of their products (Khandelwal, 2010), by refocusing their product scope on core competencies (Mayer, Melitz and Ottaviano, 2013; Liu, 2010), or by decentralizing their management hierarchy (Bloom, Sadun and Van Reenen, 2010).

In this paper we use UK firm-level data to focus on a new channel of adjustment to changes in trade policy. Namely, we demonstrate a shift toward increased provision of services in lieu of goods production. An initial look at the data suggests that this shift was potentially significant. Between 1997 and 2007 UK manufacturing import tariffs fell from an average of about 7 percent to about 3 percent, mostly as a consequence of the implementation of the Uruguay Round. ${ }^{1}$ At the same time, UK manufacturing experienced a shift toward services provision relative to goods production (Figure 1). This relative decline in domestic goods production was accompanied by a leveling off of domestic production in absolute terms and happened despite the fact that overall demand for goods grew rapidly over the period. ${ }^{2}$ The reorientation toward services has also been important for overall activity in the manufacturing sector. For instance, the growth in services revenues within the manufacturing sector during this period contributed three percentage points to the manufacturing share of total UK output. ${ }^{3}$ Thus, the long-running relative decline of manufacturing has at least in part been slowed by manufacturing becoming more services-oriented.

The shift into services production is also visible at the level of individual firms. Figure 2 plots the change in goods production versus the change in services provision for individual firms over the period 1997-2007. The negative relationship is highly statistically significant and suggests that the shift towards services took place at the level of individual firms, and was not simply a consequence of the reallocation of output shares toward more service-intensive firms or sectors. ${ }^{4}$ Considered in light of these trends, existing UK firms seem to have been, on average, re-orienting production toward services.

\footnotetext{
${ }^{1}$ See Figure A3 in the Online Appendix, available at http://web.ics.purdue.edu/ asoderbe/Papers/BSW_Appendix.pdf

${ }^{2}$ The value of UK manufacturing output grew less than half a percent per year over the period while total UK goods consumption nearly doubled. See ONS (2007a).

${ }^{3}$ Services produced by manufacturing firms count as manufacturing output in UK national accounts statistics. If we remove the increase in such services sales between 1997 and 2007 from our data (described in more detail below), we obtain a manufacturing share of 10 percent in 2007, instead of 13 percent if services sales are included.

${ }^{4}$ The coefficient of the regression line in Figure 2 is -0.58 with a standard error of 0.02 .
} 
In this paper we use firm-level data for the UK over the period 1997-2007 to further explore the link between reductions in manufacturing import tariffs and the firm's tradeoff between goods production and the provision of services. We find that lower tariffs are associated with a shift to greater services provision relative to goods production. These results are robust to controlling for changes in manufacturing export tariffs, changes in services trade barriers, firm fixed effects and a number of time-varying firm-level covariates, as well as industry-specific time trends. We also show that the relative increase in services provision in response to lower manufacturing tariffs is driven by both an absolute reduction in goods production and, in particular, an absolute increase in services provision.

We discuss a number of potential mechanisms that could explain these results by generating a link between services and goods production within the firm. One possibility is that firms' goods and services outputs may be subject to demand complementarities. However, this possibility seems to be ruled out by the strong negative association between manufacturing and service outputs within firms. It is also inconsistent with the positive impact of lower goods tariffs on services, conditional on several possibly confounding covariates. A second mechanism which is potentially more in line with the evidence is the possibility that UK firms' relative provision of services rose due to an increase in offshoring activity. In other words, UK firms might respond to goods trade liberalization by moving their goods production overseas to foreign affiliates or arms length suppliers, while intensifying their focus domestically on headquarter services. In our empirical analysis we find that this channel was relatively unimportant. Third, firms may adjust to trade liberalization by selling industry-specific expertise that they have accumulated over time as goods producers, which they can subsequently sell in the form of services. Finally, we also consider a more traditional Heckscher-Ohlin-type mechanism in which trade liberalization drives UK manufacturing firms towards specialization in skill-intensive services production.

We attempt to distinguish between Heckscher-Ohlin mechanisms and an "expertisedriven" increase in service provision by augmenting our regression specification with a number of interaction terms. We interact import tariffs with traditional Heckscher-Ohlin variables such as initial average wages (as a proxy for workers' skills) and initial capital intensity as well as with a proxy for a firm's accumulated expertise (initial R\&D stocks normalized by firm sales). ${ }^{5}$ The empirical results suggest a prominent role for the R\&D proxy for expertise in facilitating the transition to more intensive services provision in the face of goods market trade liberalization. In contrast, higher capital intensity and

\footnotetext{
${ }^{5}$ The use of the R\&D stock as a measure of accumulated expertise has a long history beginning with Griliches (1979).
} 
higher average wages are found to be relatively unimportant. These results are robust to controlling for additional interaction terms such as firm productivity and initial service intensity, which might be correlated with R\&D intensity. We interpret these findings as favoring an expertise-based mechanism although we acknowledge that they are also consistent with a more sophisticated comparative advantage story in which UK firms' comparative advantage is to be found in expertise-intensive (rather than skill- or capitalintensive) production.

Our finding that the firm's stock of accumulated expertise is important in promoting production flexibility is consistent with a strand of the management literature. For instance, Wiklund and Sheperd (2003) argue that "Knowledge about markets and technology...potentially have strong performance implications because they increase the ability to discover and exploit opportunities". A somewhat smaller literature brings these ideas closer to the context we explore here by documenting the "servitization" of manufacturing. Neely, et al. (2011) document global trends in servitization, finding that around the world approximately 30 percent of manufacturing firms with over 100 employees produce services. ${ }^{6}$ In a review of this literature, Baines, et al. (2009) note that a particular focus of the literature is on service provision as "an opportunity to differentiate from products originating from lower cost economies", which is in line with the question we address here. In contrast to this line of research, we apply a formal econometric strategy to explore a specific determinant of the shift to increased services provision by goods producers, namely trade liberalization. We show that this determinant was quantitatively important over our sample period, with the average tariff reduction leading to an approximate 50 percent rise in firms' services-to-goods ratio, compared with firms that saw no tariff reduction.

The paper follows a line of literature that explores the within-firm response to trade and trade liberalization. Several papers document the role of trade in promoting firm productivity growth (e.g., Pavcnik (2002), Bernard, et al. (2006a)) as well as innovation and technology adoption (e.g., Bloom, et al. (2016), Lileeva and Trefler (2010), or Bustos (2011)). Somewhat related to this paper, Bernard et al. (2006b) show that U.S. manufacturing firms that are more exposed to import competition from low-wage countries are more likely to switch their domestic industry. More closely related to this paper, Bernard, et al. (2017) show that Danish manufacturing firms have been switching industries, toward services, and furthermore that for a subset of these firms R\&D plays an important role in the transition.

The paper is organized as follows. Section 2 describes the data and provides additional descriptive statistics documenting the nature of services activities carried out by UK

\footnotetext{
${ }^{6}$ See also Crozet and Milet (2016) who document the servitization of French manufacturing.
} 
manufacturing firms. Section 3 provides a discussion of the potential mechanisms at work and Section 4 describes our research design and specifications. Section 5 presents the results and Section 6 concludes.

\section{Data \& Stylized Facts}

\section{Firm Data}

The primary dataset used is the UK Annual Respondents Database (ARD), which contains firm-level variables over the period 1997-2007. ${ }^{7}$ The ARD is drawn from an underlying register of the (near) universe of UK businesses. The data consist of the full population of large businesses (those with more than 100 or 250 employees depending on the year) as well as a random sample of smaller businesses. Here we focus narrowly on the manufacturing sector. Firms self-report their main industry of activity upon registration with Companies' House, the UK agency responsible for incorporating companies and maintaining a firm registry. Once registered, firms can (self-) report changes in their industry classification although in practice this happens only rarely, even if a firm's output mix changes substantially. ${ }^{8}$ We include all firms in our sample that report that their primary activity is in manufacturing in the first year they appear in the data, and we use their industry code in that year to link in our trade barrier measures (see below). ${ }^{9}$

The ARD includes many establishment-level variables and, for our purposes, the most relevant will be the total value of services provided by the establishment, the total value of services exported by the establishment, and the total value of goods produced. Additionally, the ARD allows us to construct the physical capital stock of each firm by applying the perpetual inventory method to annual firm investments in plant and machinery. Our labor productivity measure is also recorded in the ARD data as firm value added per worker and the average firm wage is the wage bill per worker.

Additionally, we augment the ARD with the International Trade in Services Inquiry (ITIS). The ITIS survey collects data on international transactions in services by private sector companies resident in the UK, and is the main input into the trade in services

\footnotetext{
${ }^{7}$ For a comprehensive description of this dataset see Criscuolo, Haskel and Martin (2003) or for a summary see Breinlich and Criscuolo (2011). We note that we begin our sample in 1997 because this is the first year that the ARD contains information about firms' services output.

${ }^{8}$ Less than 1 percent of the firms in the ARD report major changes in sectoral classification (switching from manufacturing to services or vice-versa). As a result, around 5 percent of manufacturing firms report more service than goods sales. This pattern seems to be even more pronounced in other countries. For example, Crozet and Milet (2014) report that in 2007, 33 percent of French firms classified as manufacturing firms were selling more services than goods.

${ }^{9}$ Our results are virtually identical if we also include the small number of firms that start in services but transition into manufacturing (we use their first manufacturing industry code to link in the trade barrier data in that case).
} 
account in the UK balance of payments (ONS, 2007b; Breinlich and Criscuolo, 2011). The ITIS covers firms with ten or more employees and samples around 20,000 firms per year (before 2001 this was 10,000), oversampling firms that are likely to be services traders. In contrast to the ARD, the ITIS asks about the types of services exported or imported, and the countries of destination or origin of exports and imports. The ITIS distinguishes between 38 types of services (grouped into 10 aggregate categories) and records trade with around 220 foreign countries and territories. We can use the ITIS to obtain an outline of the service export activities of manufacturing firms. Table 1 lists the types of services exported by UK manufacturing firms along with their prevalence in the data. Notably, Royalties and Licenses and Technical Services are the two most common services exports by manufacturing firms, followed with some distance by Agricultural, Mining, and On-Site Processing Services, as well as Business and Professional Services. ${ }^{10}$

Finally, we combine the ARD data with information on the annual R\&D investments by firms, drawn from the Business Expenditure on Research and Development (BERD) dataset. We construct the R\&D stock for each firm using the perpetual inventory method applied to the BERD flows, adopting an economic depreciation rate of 30 percent. ${ }^{11}$ Throughout, we normalize this measure by firm revenue in order to capture firm intensity in $\mathrm{R} \& \mathrm{D} .^{12}$

Our final dataset contains up to 45,000 individual firms depending on the specification (as noted in the regression tables), covering 225 manufacturing industries at the 4-digit level of the UK Standard Industrial Classification (UK SIC) over the period 1997-2007. ${ }^{13}$ As noted, the sample of small firms in the ARD is a repeated cross-section, such that small firms' tenure in our dataset is variable and usually short. ${ }^{14}$ In addition, there is quite a bit of churning of firms into and out of our sample though the extent of the churning is stable across years. The most important reason for sample exit is the sample design underlying the ARD, and in particular the random sampling of small and mediumsized firms. ${ }^{15}$ Nevertheless, we discuss this issue further in our robustness checks and

\footnotetext{
${ }^{10}$ Note that the ARD only contains the total value of service production (i.e., not by service type), so that we cannot provide a similar breakdown for overall service production.

${ }^{11}$ We choose this value following the convention in the literature - see, for instance, Bloom, Griffith and Van Reenen (2002). However, our results are virtually unchanged for values near this.

${ }^{12}$ We scale the R\&D stock by firm revenue in order to capture firm intensity in $R \& D$. This is consistent with the idea that even small firms who are relatively R\&D active may apply their accumulated expertise to services provision. Stated differently, we do not believe that firm size, and hence the absolute size of the R\&D stock, is necessarily the key determinant of the likelihood of transition.

${ }^{13}$ In specifications that include the $R \& D$ stock variable the number of firms is reduced due the smaller sample of firms drawn for the BERD.

${ }^{14}$ Online Appendix Table A2 documents the number of firms in our dataset by tenure, where we see that indeed the most common tenure is one year.

${ }^{15}$ See Partington (2001) for details. As discussed, larger firms are always sampled. Medium-sized entreprises (between 10 and 100 to 250 employees) are rotated out of the sample at a rate of 50 percent per year, meaning that half the businesses that are in the survey in year one are also included for year
} 
provide evidence that sample entry/exit is unlikely to be problematic for our results. For example, we show that our results are almost identical across sub-samples that include firms with relatively short or relatively long tenures in our dataset. We also present results for attrition probability regressions which show that the probability of actual exit (as opposed to exit from the sample) in response to tariff cuts is not higher for firms with initially lower service shares. ${ }^{16}$

\section{Trade Barrier Data}

Import tariffs $\left(\tau_{j t G}^{\mathrm{M}}\right)$ for each industry and year in our sample are collected from the World Trade Organization (WTO) Tariff Database. We focus on Most Favored Nation (MFN) tariffs, which do not vary across WTO member countries. We aggregate tariff line information to the 4-digit UK SIC level using concordances provided by the United Nations Statistics Division and taking simple averages across tariff lines. Note that changes in MFN tariffs were the most important source of variation during our sample period in the European Union's (EU) (and hence the UK's) external tariff, in the sense that they applied to imports from all other WTO members, covering almost all of the UK's imports from outside the EU. The EU also negotiated a number of free trade agreements between 1997 and 2007 but these were with smaller trading partners which accounted for only a small share of the UK's non-EU trade. ${ }^{17}$ While average MFN import tariffs were already relatively low in 1997 (around 5\%), this average hides substantial sectoral heterogeneity. In 1997, ad-valorem tariffs ranged from 0 percent to over 40 percent in some sectors. By 2007, average tariff levels had halved to around 2.5 percent and the highest tariffs to just over $20 \%$, implying tariff reductions of up to 20 percentage points.

Our empirical strategy also requires average goods export tariffs $\left(\tau_{j t G}^{\mathrm{X}}\right)$ faced by UK firms in foreign destinations. These come from the United Nations' Trade Analysis and Information System (TRAINS) as cleaned and expanded by Feenstra and Romalis (2014). ${ }^{18}$

two. Smaller businesses are usually only included for one year, meaning that the exit rate for such firms is $100 \%$. Using these re-sampling probabilities by size band together with the number of firms in each band yields an average resampling-induced exit probability of around $45 \%$. As a consistency check, we have also computed an indicator for true firm exit (as opposed to exit from the ARD sample) using the UK's firm register (the BSD) from which the ARD sample is drawn. This shows that the average true exit probability for the firms that appear in our sample at some point is indeed only around $4.5 \%$ per year, again suggesting that only a small part of the sample exit rate of $49-51 \%$ reported in Table 2 is due to true exit.

${ }^{16}$ In Online Appendix Table A3 we further document for each two-digit industry the average number of firms and average industry sales over 1997-2007.

${ }^{17}$ See http://ec.europa.eu/trade/policy/countries-and-regions/agreements/index_en.htm for a list of EU trade agreements. Importantly, MFN tariffs applied to all of the UK's major non-EU trading partners such as the U.S., Japan and China. (China had been granted most-favored nation status by the EU in 1985, long before its eventual WTO accession in 2001.)

${ }^{18}$ We thank John Romalis for making these data available to us. 
We aggregate these product-destination-year specific tariffs in two steps. First, using a concordance between SITC and UK SIC provided by the United Nations Statistics Division, we construct destination-specific export tariffs at the UK SIC 4-digit level by taking simple averages across the SITC tariff lines mapping into a given UK SIC code. We then aggregate across destination countries using average trade shares of each destination country in total UK exports between 1994-1996. The resulting average ad valorem tariff varies at the year and 4-digit SIC-level, and captures the average goods export barriers faced by UK manufacturing firms in a given industry and year. ${ }^{19}$

In one of our robustness checks we also control for intermediate input tariffs for goods which we compute as the weighted average of the UK import tariffs of all industries $k$ supplying a given industry $j$ :

$$
\text { Input tariff }_{j t}=\sum_{k} w_{k j} \times \tau_{k t G}^{\mathrm{M}}
$$

where $\tau_{k t G}^{M}$ is industry k's goods import tariff (described above) and $w_{k j}$ is the cost share of industry $k$ in the production of goods in industry $j$ in 1995. We obtain information on $w_{k j}$ from the UK's input-output table for 1995 (ONS, 2002).

For measures of services trade barriers $\left(\tau_{j t S}^{\mathrm{M}}\right.$ and $\left.\tau_{j t S}^{\mathrm{X}}\right)$ we rely on the OECD's Product Market Regulation (PMR) index which quantifies barriers to services trade in different service types for OECD and selected third countries. ${ }^{20}$ Unfortunately, there is no existing concordance between these service types and UK SIC industries. Thus, in a first step we need to determine the service types that correspond to each SIC industry. To do this, we focus on the service types that are imported and exported by firms in a particular SIC industry, obtained from the UK ITIS. For imports, we compute the share of each service type imported by the firms in a given sector in the total service imports of these firms. We then use these shares as weights to aggregate the service-type specific trade barriers from the PMR to obtain UK SIC-specific import barriers. ${ }^{21}$ For exports, we first compute service-type weights in a similar manner and calculate destination-industryspecific export barriers by combining the weights and the service-specific barriers for each foreign country reported by the OECD PMR index. Similar to goods export tariffs, in a final step we aggregate across all foreign countries using the share of each country in

\footnotetext{
${ }^{19}$ We use simple averages or pre-period weights to avoid or reduce endogeneity problems arising from the use of contemporary trade weights (that are themselves a function of tariffs).

${ }^{20}$ These data are available at www.oecd.org/economy/growth/.

${ }^{21}$ We use the first year in our sample (1997) to construct these weights in order to reduce endogeneity problems. Unfortunately, no firm-level service import data is available prior to 1997 so that we cannot use pre-sample weights as for our goods export tariffs. Note that constructing weights at the industry rather than the firm level helps reducing endogeneity problems from using trade-based weights. We also experimented with using simple averages across all service types imported by firms in a given sector, with similar results.
} 
total UK services exports between 1994-1996.

Note that for most of our analysis, our focus will be on the effect of import tariffs on the relative mix of service and goods production, controlling for the other trade barriers just discussed. Tariffs have a number of important advantages over other measures of the intensity of import competition. Most importantly, they are under the direct control of policy makers, rather than being determined by a complex array of additional general equilibrium forces, as is the case for import penetration ratios. As such, understanding the impact of tariff changes on service intensity is of much more direct policy relevance. ${ }^{22}$

Second, tariffs are arguably more exogeneous than general equilibrium outcomes such as imports. This is particularly true in our setting, given that both manufacturing import and export tariffs are negotiated by the European Commission for the European Union as a whole, making them less likely to be endogenous to UK industrial trends. Also note that in contrast to regional trade agreements, MFN tariff changes are the result of multilateral negotiations involving a large number of countries, making it more difficult for individual firms or sectors to influence their outcome. Indeed, this is another important reason for why we focus on MFN tariffs. Services trade barriers are more heterogeneous and still more influenced by national policies. But even here, bilateral negotiations with other countries and trading blocks fell within the remit of the European Commission for the second half of our sample period, and services barriers were brought into the remit of the World Trade Organization as part of the Uruguay Round. ${ }^{23}$ We return to this issue in Section 4 below where we report additional econometric evidence for the exogeneity of tariff reductions and discuss potential remaining issues. In Section 5, we also show that our results are robust to using (likely endogenous) import penetration ratios instead of import tariffs.

\section{Stylized Facts}

This section presents basic descriptive statistics on the provision of services by UK manufacturing firms. To begin, we restate two findings presented in the introduction. Figure 1 documents the share of services revenues in total revenues across all UK firms between 1997 and 2007. We see that since 1997 the fraction of service activity within manufactur-

\footnotetext{
${ }^{22}$ See for instance Rodriguez and Rodrik (2000) and Trefler (2004) for a discussion of this point and a criticism of more indirect measures such as import penetration ratios. In any case, below we demonstrate that regressing service shares on import penentration ratios instead of import tariff yields qualitatively similar results.

${ }^{23}$ The European Commission obtained explicit powers to negotiate services trade policy in addition to goods trade policy in the Treaty of Nice (2001). Trade policy in services is restricted by the General Agreement on Trade in Services (GATS) of 1995, although it is still unclear to what extent the Uruguay Round triggered a liberalization of services trade in addition to goods trade (see Francois and Hoekman, 2010).
} 
ing firms has grown steadily, reaching 20 percent in 2007. Figure 2 then plots the average annual change in services revenue over the period against the change in goods revenue for each firm in the sample. The fitted line indicates that, on average, goods and services are substitutes within the firm. ${ }^{24}$

Focusing in more detail on the evolution of services provision within UK firms, Table 3 provides further information on the evolution of manufacturing firms' services shares and a number of firm-level covariates (average wages, capital and R\&D stocks and total revenues). Specifically, we regress the annual percentage-point change in the share of services in total output (i.e., share $_{t}-$ share $_{t-1}$ ) on firm-level variables measured at the beginning of the period (i.e., at $t-1$ ). As seen, higher initial wages, R\&D stocks and total output are associated with a stronger shift into services, whereas the initial capital stock is negatively (though insignificantly) correlated with the change in the services share. Interestingly, when we include all four determinants jointly, only the coefficient on initial R\&D stocks remains positive and significant.

\section{Mechanisms}

Here we highlight potential theoretical channels through which trade liberalization may affect relative goods output and services provision at the level of the firm over time. First, it may simply be the case that a firm's goods and services outputs are complements on the demand side. For example, a firm may produce a product that requires some level of ongoing support, such as a manufacturer who provides regular service on their product for some period after purchase. In this case we would observe a strong, positive relationship between the level of goods and services output at the firm level, and a simultaneous reduction in both output types in the face of trade liberalization. However, in light of the fact that we find a strong, negative correlation between goods and services production within firms, we rule this out as a potential explanation for our results.

We focus instead on three alternative channels. First, a Heckscher-Ohlin mechanism - in which increased global engagement by low-skill abundant developing countries alters global production patterns - may have impacted the relative provision of services across UK firms. More specifically, from the UK perspective increased firm specialization according to comparative advantage would lead to a shift toward greater skill-intensive production, particularly within industries that are overall skill-intensive (see Crozet and Trionfetti, 2013, for a model of firm-level comparative advantage) ${ }^{25}$ Since many UK

\footnotetext{
${ }^{24}$ The coefficient of the regression line in Figure 2 is -0.58 with a standard error of 0.02 .

${ }^{25}$ Crozet and Trionfetti (2013) show that firms that are intensive in the factor used intensively in their industry and of which their country is relatively well endowed have a comparative advantage over firms with identical factor intensity in other countries.
} 
manufacturing industries are likely to be relatively skill-intensive, this comparative advantage mechanism may manifest as an on-average firm-level shift toward increased use of skill, which may correlate with an increase in relative services provision to the extent that services are skill-intensive. We return to this prediction in Section 5.

Second, import competition in the goods market may lead to increased offshoring of goods production by UK firms. There is, of course, a large literature exploring the decision by multinational firms to increasingly locate headquarters services in human-capitalrich developed countries while offshoring low-skill-intensive aspects of the production process to developing countries. ${ }^{26}$ By focusing narrowly on a firm's activities within a single country (as we do) one may mistakenly attribute increased offshoring to an overall decline in goods production by firms. This may lead to an observed relative rise in the services share for all firms, and particularly for initially low-skill intensive firms who have the greatest incentive to engage in offshoring (see Grossman and Rossi-Hansberg, 2008 or Wright, 2014). With respect to this potential channel, we can test directly for an offshoring response to trade liberalization, and we do so in Section 5.

Finally, a shift toward increased relative provision of services may reflect a shift toward sales of accumulated expertise by UK firms. In other words, over time firms may accumulate industry- and product-specific expertise as a byproduct of their research, development and production of goods, and this expertise may be embodied by workers within the firm. When confronted with increased competition in the goods market, firms may then leverage this knowledge in the market for services. In effect, the firms can sell their accumulated market-specific expertise in lieu of goods. However, since the knowledge is embodied, the switch to services will come at the expense of goods production. One version of this mechanism is explored by Bloom et al. (2012). In their "trapped factors" model the opportunity cost of producing services (in their case the focus is on the opportunity cost of innovation, but the model's mechanism is not specific to this case) falls in the face of increased import competition in goods due to the fact that there are adjustment costs associated with moving factors out of one output type and into another. Alternatively, in the Online Appendix we present a similar model in which firm-specific expertise is rival in its use across output types (goods or services) but where larger stocks of expertise reduce the magnitude of the rivalry, thereby making it easier for the firm to transition out of one output type and into another. In both cases it is an increase in the relative profitability of services due to a rise in import competition in the goods market that induces the transition. In this case there are two primary empirical predictions that would be observable in our data. First, the switch to services provision may again be relatively pronounced among low-skill intensive firms as skilled workers are brought on-

\footnotetext{
${ }^{26}$ See Crinò (2009) for a review of this literature.
} 
board to a greater extent among these most-affected firms, a prediction that is difficult to distinguish from the more straightforward Heckscher-Ohlin mechanism described above. However, a second prediction is that the shift toward increased services provision should be greater within firms that ex ante perform more R\&D (a proxy for expertise), and we explicitly test this hypothesis in Section 5.

In sum, each of these channels may lead to a within-firm shift toward a more-skilled workforce, which we will proxy with the firm's average wage. ${ }^{27}$ However, beyond this, the second channel predicts an increase in offshoring. To explore this channel we focus on the fact that offshoring is typically associated with an increase in exports of headquarters services, which we can observe. Finally, the third channel predicts a rise in R\&D intensity within the firm, and we explore this channel by exploiting available R\&D data. We keep these implications in mind and refer back to them in the empirics.

\section{Empirical Approach}

In this section we explore the magnitude of the within-firm response to trade liberalization. Specifically, we estimate specifications relating the ratio of a firm's revenues from services relative to goods $\left(R_{i j t S} / R_{i j t G}\right)$ to reductions in MFN import tariffs. We also include a number of additional firm- and sector-level controls to further reduce the threat of omitted variable bias and to increase the precision of our estimates. At the sectoral level, we control for variation in the other three trade barriers affecting UK firms - i.e., UK import and export barriers for services trade as well as the export tariffs faced by goods producers. Variation in any of these trade barriers will clearly have a direct impact on the optimal choice of production of goods relative to services and we therefore want to control for these potential determinants of relative output. At the level of individual firms, we control for the average wage bill, as a proxy for input prices and the skill level of the work force, and labor productivity, as a proxy for firm-specific productivity shocks. ${ }^{28}$ In addition, we include year fixed effects, which will capture any macro-level trends in input prices and technologies; and in our preferred specifications we add firm fixed effects and two-digit industry time trends to control for firm-specific time-invariant factors and productivity trends as well as trends in aggregate expenditure on each industry's output.

Finally, we note that our baseline specification, while formally atheoretical, is consistent with the equilibrium ratio of services to goods output implied by a straightforward monopolistic competition model, an example of which we present in the Online Appendix.

\footnotetext{
${ }^{27}$ Unfortunately, the ARD does not contain information on skill levels, so we cannot use a more direct proxy.

${ }^{28}$ We acknowledge that wages and productivity are potentially endogenous. As we show below, excluding them does not affect our results.
} 
These considerations lead us to the following reduced-form specification relating the ratio of a firm's revenues from services relative to goods $\left(R_{i j t S} / R_{i j t G}\right)$ to the channels discussed above:

$$
\frac{R_{i j t S}}{R_{i j t G}}=\exp \left[\eta_{i}+\theta_{t}+\beta_{1} \tau_{j t G}^{\mathrm{M}}+\beta_{2} \tau_{j t G}^{\mathrm{X}}+\beta_{3} \tau_{j t S}^{\mathrm{M}}+\beta_{4} \tau_{j t S}^{\mathrm{X}}+\beta_{5} \ln \bar{w}_{i j t}+\beta_{6} \ln \psi_{i j t}+\rho_{m} t\right]+\epsilon_{i j t}
$$

where the $\tau$ 's represent import $(M)$ and export $(X)$ barriers for goods $(G)$ and services $(S)$ associated with firm $i$ 's industry $j$. Firm and year fixed effects are denoted by $\eta_{i}$ and $\theta_{t}$, respectively. The firm's average wage and labor productivity are $\bar{w}_{i j t}$ and $\psi_{i j t}$, and $\rho_{m} t$ is a 2-digit industry time trend. The main coefficient of interest is on goods import tariffs, $\beta_{1}$, since its sign indicates whether firms react to tariff reductions by increasing services output relative to goods output $\left(\beta_{1}<0\right)$ or by reducing it $\left(\beta_{1}>0\right)$. While our main interest is in the output of services relative to goods, we also estimate versions of (1) in which we use goods or services revenues separately as the dependent variable. This allows us to evaluate whether changes in relative revenues are driven by goods, services, or both. ${ }^{29}$

We have chosen an exponential conditional mean function for our baseline specifications, which we estimate via Poisson Pseudo-Maximum Likelihood (PPML) techniques. The use of PPML estimation is motivated by two specific features of our data. First, there are many zeros for the value of services revenue - i.e., the majority of firms in our data do not provide services. ${ }^{30}$ A log-linear specification would thus need to drop a large part of the sample. Second, given the highly skewed distribution of revenues across firms it is unlikely that the unexplained variation in (1), or its counterparts with goods and services revenues only, will be homoskedastic. As Santos-Silva and Tenreyo, 2006 point out, the log of the error term will then be correlated with the regressors, due to the mechanical correlation between the mean and variance of a logged variable. PPML estimation addresses both of these issues and, importantly, seems to be a superior estimator relative to alternatives such as Tobit or Gamma PML (see Santos-Silva and Tenreyo, 2006, or Head and Mayer, 2013). ${ }^{31}$ Throughout, we cluster standard errors at the 4-digit

\footnotetext{
${ }^{29}$ Note that we use contemporaneous variation in tariffs rather than lags or leads. On the one hand, it may take time to expand services production relative to good production. On the other hand, the tariff reductions agreed to in the Uruguay round were phased in over several years and the reduction schedule was widely publicized. Thus, UK firms would have been aware of the timing of tariff cuts and might have started the shift into services production before the actual reductions took place. Using contemporaneous variation strikes a balance between these opposing arguments and also maximizes our sample size.

${ }^{30}$ In our baseline specification (see Table 4 below), 70 percent of firm-year observations for service revenues and the ratio of services to goods revenues are zero.

${ }^{31}$ Note that the coefficient on goods tariffs $\left(\beta_{1}\right)$ measures a semi-elasticity as can be verified by dif-
} 
industry level because our regressor of interest $\left(\tau_{j t G}^{\mathrm{M}}\right)$ only varies by 4 -digit industry and year.

In an additional set of specifications we interact a number of firm-level variables with goods import tariffs in order to explore the underlying features that are predictive of a successful transition toward greater relative provision of services in the face of trade liberalization. This will also be helpful in discriminating between the remaining mechanisms discussed in Section 3 (Heckscher-Ohlin versus accumulated expertise). Specifically, we look at the role of firm intensity in skill, firm intensity in capital, and the firm's accumulated expertise. To do this we proxy the average skill level of the firm with the average firm wage in the first year we observe a firm in our data. ${ }^{32}$ We also exploit data on the firm's initial period capital stock and the firm's initial R\&D stock (both normalized by total firm revenues) in order to proxy for capital intensity and firm expertise, respectively. We focus on these time-invariant measures in order to mitigate the potential endogeneity between our dependent variable and each of these variables over the period. Finally, we add terms that interact the firm's initial labor productivity and initial level of services provision with goods tariffs, since these may be correlated with a firm's overall capacity to provide services. ${ }^{33}$ Formally, we estimate versions of the following specification: ${ }^{34}$

$$
\begin{aligned}
\frac{R_{i j t S}}{R_{i j t G}}= & \exp \left[\eta_{i}+\theta_{t}+\alpha_{1}\left(\ln R \& D_{i j} \times \tau_{j t G}^{\mathrm{M}}\right)+\alpha_{2}\left(\ln \operatorname{Cap}_{i j} \times \tau_{j t G}^{\mathrm{M}}\right)+\alpha_{3}\left(\ln \psi_{i j} \times \tau_{j t G}^{\mathrm{M}}\right)\right. \\
& +\alpha_{4}\left(\ln \bar{w}_{i j} \times \tau_{j t G}^{\mathrm{M}}\right)+\alpha_{5}\left(\ln \operatorname{InitServ}_{i j} \times \tau_{j t G}^{\mathrm{M}}\right)+\alpha_{6} \tau_{j t G}^{\mathrm{M}}+\alpha_{7} \tau_{j t G}^{\mathrm{X}}+\alpha_{8} \tau_{j t S}^{\mathrm{M}}+\alpha_{9} \tau_{j t S}^{\mathrm{X}} \\
& \left.+\alpha_{10} \ln \bar{w}_{i j t}+\alpha_{11} \ln \psi_{i j t}+\rho_{m} t\right]+\varepsilon_{i j t}
\end{aligned}
$$

where $R \& D_{i j}$ and $C a p_{i j}$ denote a firm's initial $\mathrm{R} \& \mathrm{D}$ and capital stock, $\psi_{i j}$ and $\bar{w}_{i j}$ its initial productivity and average wage, and InitServ $v_{i j}$ its initial service share. All remaining regressors are as in specification (1). We are particularly interested in the interaction term coefficients $\alpha_{1}, \alpha_{2}, \alpha_{3}, \alpha_{4}$ and $\alpha_{5}$.

ferentiating (1) with respect to $\tau_{j t G}^{\mathrm{M}}$. The corresponding OLS specification (which would produce biased estimates) would be a regression of the $\log$ of $R_{i j t S} / R_{i j t G}$ on the tariff variable. As a simple illustrative exercise to show that $\log \left(R_{i j t S} / R_{i j t G}\right)$ is not dominated by outliers, we plot its distribution in the Online Appendix, Figure A1, though again we note that taking the log leads to a large amount of zeros being dropped.

${ }^{32}$ Unfortunately, the ARD does not contain information on more direct proxies for skill intensity, such as education levels or the share of white-collar workers.

${ }^{33}$ Labor productivity might play a role if the transition into services production requires a fixed cost investment. This investment would only be profitable for more productive firms and we should observe a stronger shift into services for such firms in response to the tariff reductions.

${ }^{34}$ Note that the main effects of the initial firm-specific variables are subsumed in the firm fixed effects. 


\section{Empirical Results}

In this section we present our empirical results. We first show that lower manufacturing import tariffs were associated with increased services provision relative to goods production on average. We then explore the robustness of our results and analyze the firm characteristics that influence the extent of the transition into services.

\section{Firm Response to Trade Liberalization}

\section{Baseline Results}

Table 4 presents the results from estimating equation (1). In column (1), we include only the import barriers for goods and services as well as year fixed effects. Columns (2)-(7) add additional regressors and fixed effects which progressively make the specifications more restrictive. In column (2), we add export barriers for goods and services, column (3) adds firm-level wages and labor productivity and in column (4) we control for 4-digit industry fixed effects. Finally, columns (5)-(7) add firm fixed effects, where columns (5) and (6) compare the estimates with and without the potentially endogenous firm average wage and productivity controls, while column (7) adds two-digit industry time trends.

Throughout Table 4, the coefficient on our main variable of interest (manufacturing import tariffs) is negative and highly statistically significant, indicating that lower import tariffs are associated with higher services revenues relative to goods revenues. This suggests that, at least on average, firms shift toward increased provision of services in the face of falling import barriers. We further note that the inclusion or exclusion of (potentially endogenous) wage and productivity controls has little effect on the estimates. Finally, controlling for industry or firm fixed effects leads to a steep fall in the coefficient on goods tariffs, suggesting that there is a significant amount of unobserved heterogeneity across firms and industries that is correlated with tariff reductions. The fact that coefficient estimates also change (albeit less) when industry fixed effects are replaced with firm fixed effects further implies that unobserved within-industry heterogeneity might also be a problem. By contrast, including industry-time trends leaves coefficient estimates basically unchanged. We thus consider our firm fixed effects regressions (with or without industry-time trends) to be the most reliable specifications and focus on them for most 
of the subsequent discussion and results. ${ }^{35,36}$

We next explore whether the shift to greater relative services provision is due to higher services revenues, lower goods revenues or a combination of both. Tables 5 and 6 are similar to those in Table 4, but replace relative revenues by services and goods revenues, respectively. We see that lower manufacturing import tariffs led to both higher services revenues and lower goods revenues. ${ }^{37}$ The results are most significant for services revenues, where we find a negative and highly significant coefficient on goods import tariffs in all but column (4). For goods, the results are slightly less robust, but the relevant coefficient is also either positive and significant or insignificant, indicating that lower manufacturing import tariffs did decrease goods revenues, or at least did not increase them.

\section{Economic Significance}

We now look more closely at the economic significance of our baseline estimation. A first approach is to compare the magnitudes implied by our coefficient estimates to the actual shift into services observed during our sample period. According to our preferred specifications (columns 5-7 in Table 4), a one percentage point reduction in goods import tariffs led to an approximate increase of 18-22 percent in the ratio of services to goods revenues. Over the period 1997-2007, goods import tariffs declined by 2.5 percentage points on average across industries. This implies that the services to goods ratio increased by around 45-55 percent in the average industry compared to an industry that saw no tariff reductions at all. For comparison, the (unweighted) mean of the services-to-goods ratio across the firms in our sample doubled from 5 percent to 10 percent between 1997and

\footnotetext{
${ }^{35}$ Note that the number of observations drops sharply when we include firm fixed effects. This is because firms with only one year of tenure in the data and firms whose service-to-goods ratio does not change over time do not contribute to the Poisson likelihood function and are dropped from the data (see Cameron and Trivedi, 1998). In the Appendix we replicate results for columns (1)-(4) for the smaller sample used for the firm fixed effects regressions. The results are almost identical to column (1)-(4) in Table 4, demonstrating that the change in coefficient estimates is due to the inclusion of firm fixed effects rather than changes in sample composition.

${ }^{36}$ In contrast to goods import tariffs, results for our remaining trade barrier measures (goods export tariffs and services import and export barriers) are less consistent across columns and are mostly insignificant. One explanation for this is that they are much less precisely measured that import tariffs. Export tariffs are a trade-weighted average across the import tariffs imposed by foreign countries, so that the same measure applies to different UK firms in the same industry, irrespective of their actual export patterns. For services, an additional problem is that services barriers are much harder to measure. In contrast to goods trade, where tariffs provide a simple and easily quantifiable restrictiveness measure, barriers for services include a wide range of regulatory and policy instruments.

${ }^{37}$ In unreported results (available on request) we find that the effect on total sales (goods plus services) is close to zero and not statistically significant for most specifications, including our preferred ones with firm fixed effects.
} 
2007.38

An alternative way of highlighting the importance of the predicted increase in services production is to look at associations with other variables of interest, such as wages or employment. In Table 7 we regress a number of firm-level variables on the service-togoods production ratio. The results show that a one percent increase in the service-togoods ratio is associated with an approximate 0.08 percent increase in firm-level total sales, a 0.028 percent increase in wages, a 0.092 percent increase in employment and a 0.024 percent increase in labour productivity. (We do not find a statistically significant association with firm exit probabilities.) Recall our earlier prediction that the service-togoods ratio increased by around 50 percent in an industry with average tariff reductions compared to an industry without tariff reductions. We can use this figure together with the above correlations to compute implied changes in relative firm-level outcomes. For example, according to our estimates, the 50 percent relative increase in the service ratio linked to tariff reductions is associated with a $50 \times 0.09=4.58$ percent increase in firm-level employment in the average industry compared to an industry without tariff reductions. The last row of Table 7 reports similar implied changes for the other variables as well. Of course, we caution that these calculations are based on simple correlations and that no causal link is implied.

\section{Robustness Checks}

\section{Estimation Method and Functional Form}

We first look at the importance of functional forms, data construction and estimation method on our results. In Table 8 the dependent variable is the service intensity of the firm - i.e., the share of services in total (services plus goods) output, rather than simply the ratio of the two output types. While the coefficient magnitudes are not directly comparable to Table 4, we see that the estimates are qualitatively similar and the coefficient on goods tariffs continues to be negative and statistically significant at the one percent level. In Table 9 we estimate our baseline specification via OLS. Note that the functional form is again different from the baseline - we cannot take logs of the dependent variable because of the presence of zeros and instead regress the ratio of services to goods revenues on the same regressors as before. ${ }^{39}$ While OLS is likely to be biased for the reasons discussed above, it is reassuring to see that the results are qualitatively similar: increased trade liberalization is associated with a rise in the relative provision of services.

\footnotetext{
${ }^{38}$ Note that these figures are not directly comparable to Figure 1 because they are not size-weighted, are based on a slightly different sample, and the denominator is different (goods revenues in this section, total revenues in Figure 1).

${ }^{39}$ Our earlier PPML estimates assume an exponential conditional mean function, i.e., $E(y)=\exp (X \beta)$ so that $\beta$ estimates a semi-elasticity.
} 
Note that for conciseness, we focus on our two preferred specifications here and for each of the following robustness checks (firm fixed effects and firm fixed effects and industry trends, respectively; i.e., those corresponding to columns 6 and 7 from Table 4).

\section{Import Penetration Ratios}

Table 10 presents results using sectoral import penetration ratios instead of goods tariffs as our main regressor of interest. As we have argued above, import penetration ratios are of lesser interest to policy makers and are more likely to suffer from endogeneity problems. Nevertheless, it is reassuring to see that we obtain qualitatively similar results when using this alternative measure of import competition. As seen in Table 10, higher import penetration has a positive and significant impact on the service-to-goods ratio, with a one percentage point increase in import penetration raising relative service production by approximately $1.4 \%$.

\section{Focus on Domestic Sales}

The ratio of services to goods revenues, which is the focus of the baseline specification (1), includes exports as well as domestic sales. Export revenues from any location $n$ will depend on trade barriers imposed by that location on the exports of firm $i$ (proxied by $\tau_{j t G}^{X}$ and $\tau_{j t S}^{X}$ in specification (1)) but also on the barriers imposed on firms from third markets. Unfortunately, we do not have data for such third-market trade barriers and multi-collinearity issues would prevent their inclusion in any case. As a simple robustness check we focus instead on domestic revenues in the construction of our dependent variable, rather than total revenues (which also include export revenues). That is, we construct domestic services revenues $\left(R_{i j t S}^{D O M}\right)$ as total services revenues minus services exports. Unfortunately, for our sample period the ARD only contains data on export revenues for services but not for goods. Thus, we continue to use total goods revenues as the denominator of our dependent variable. For comparison with our earlier results from Table 4 , we also estimate a specification with $R_{i j t S}^{D O M}$ as the dependent variable.

In Table 11 (columns 1-2), we regress the newly constructed revenue ratio $\left(R_{i j t S}^{D O M} / R_{i j t G}\right)$ on the same variables as in our baseline specification. The results are very similar to our baseline results from Table 4 . When we use domestic services revenues as our dependent variable in Table 11 (columns 3-4), we obtain slightly larger coefficient estimates in absolute terms on our manufacturing import tariff regressor, but otherwise the pattern of results is very similar to the one presented in Table 5. A possible explanation for these similarities is that services exports accounted for only a relatively small fraction of total manufacturing services revenues over our sample period (19 percent on average). 


\section{Different Samples of the Data}

As noted in Section 2 the ARD dataset consists of the universe of large firms and a sample of small and medium sized firms (those with fewer than 100 or 250 employees depending on the year). As a result, some firms are in our dataset for only a brief period (often only a single year) while others are in the dataset in all years (large firms who entered prior to our period and did not exit during it). In this subsection we simply repeat our baseline specification (equation (1), estimates reported in Table 4) but estimate the regressions across a sample of firms with at least six years tenure in our dataset, and then across a sample of firms with at most five years tenure. ${ }^{40}$ We relegate these results to the Online Appendix (Table A4) but note that the estimates are virtually unchanged compared to the baseline results on the full sample. We conclude that there is nothing in particular about our sample of firms that is driving the results.

\section{Goods Tariffs - Trade Impact and Exogeneity}

We now discuss two issues related to our use of goods import tariffs as our main regressor. First, a necessary condition for all the mechanisms we discuss in Section 3 is that import tariff reductions increased import competition. A simple regression of imports and import penetration ratios on goods import tariffs confirms that goods tariff reductions did indeed lead to significant increases in imports and import penetration ratios (see Table A5 in the Online Appendix). Specifically, a one percentage point reduction in MFN tariffs led to a $9.4 \%$ increase in total UK goods imports and a 4.34 percentage point increase in the UK's import penetration ratio.

Second, as discussed in Section 2, we believe that import tariff reductions were largely exogenous given the institutional setting within which they were negotiated. Here, we provide additional evidence that individual UK firms and sectors did not influence WTO tariff negotiations in a way that is systematically related to their current outcomes (e.g., struggling UK firms may make efforts to maintain high tariffs). In Table 12 we present the results of industry-level regressions in which the dependent variable is the change in industry tariffs between 1997 and 2007 and the regressors are the industry growth rates of average wages, employment and sales in the pre-period, 1992 to 1996. In other words, we ask whether observed tariff variation is predicted by lagged industry outcomes. Table 12 suggests that these variables have no predictive power. Thus, to the extent that industry outcomes reflect the experience of the firms within those industries that are most likely to engage in lobbying, these results suggest no relationship between the

\footnotetext{
${ }^{40}$ These tenure lengths were chosen as the mid-point of the ranges of tenures in our data (one to eleven years). In unreported results we repeat the analysis for different tenure length cases, and these are available on request. The results are consistently similar across samples.
} 
outcomes of those firms and future tariff changes. We acknowledge that some endogeneity concerns might remain, however. If UK policy makers based their negotiating position on expectations about the future performance of UK industries and if these expectations influenced the EU's negotiating position and led to changes in the outcome of multilateral tariff negotiations in the WTO, tariffs could be correlated with other contemporaneous forces that also shape the transition of manufacturing from goods to services.

\section{Attrition and the Role of Firm Exit}

The main determinant of firms' disappearance from our dataset is the sampling design of the ARD, which only surveys a randomly chosen sample of smaller firms in a given year. By construction, this form of sample attrition is random and will not be related to trade liberalization. However, firms will also drop out of the sample if they go bankrupt and exit the market. This could potentially explain our results if firms that produce relatively little service output (i.e., are primarily, or solely, goods producers) are driven out of the market due to trade liberalization. In this sense the results may, in part, reflect a change in the composition of firms in the market rather than simply an on-average within-firm shift toward services. In Table 13 we report the results of a standard attrition probability regression in which the dependent variable is a binary indicator for whether a firm exits the sample due to closure at some point during the period 1997-2007. ${ }^{41}$ The regressors are the average annual change in import tariffs faced by the firm over the firm's tenure (which could be fewer than the maximum 11 years), the firm's initial goods-to-services ratio, and the interaction between tariffs and the initial ratio. We see in Table 13 that goods import tariffs are negatively related to exit probabilities although that effect is not statistically significant (column 1). ${ }^{42}$ More importantly, the coefficient on the interaction term is also close to zero and is insignificant, indicating that differential attrition is unlikely to explain our results. In columns 2-3, we also interact the three other trade barriers measures with initial goods-to-services ratio, again finding no evidence for differential attrition.

\footnotetext{
${ }^{41}$ We use the Business Structure Database (BSD) to construct this exit indicator. The BSD is constructed from snapshots of the U.K.'s business registry and essentially contains the universe of incorporated firms. Given that the ARD sample is drawn from the BSD, we can link the exit indicator to our regression sample. The indicator takes the value of one if employment reported in the BSD drops to zero or if the firm disappears from the BSD at some point during the period 97-07.

${ }^{42}$ At first sight, this seems to contradict previous findings in the literature that trade liberalization increases exit probabilities. We note, however, that our estimate is close to statistical significance (pvalue of 0.2 ) and is of economically significant magnitude (a one percentage point reduction in import tariffs increases the likelihood of exit by around 4-5 percentage points). One explanation of the lack of statistical significance might be measurement error in the dependent variable (the exit indicator). As discussed by Criscuolo, Haskel and Martin (2003), the underlying firm registry data (the BSD) does not continuously update employment information for many of the smaller firms so that firms that exit are sometimes still listed as having positive employment.
} 


\section{The Role of Offshoring}

Next, we consider evidence for one of the mechanisms discussed in Section 3 - offshoring. It is possible that the pattern observed in the regression results above may be due to an increase in geographic specialization on the part of multinationals. In other words, in response to lower manufacturing import tariffs UK firms may simply be moving their goods production overseas - i.e., offshoring goods production - while increasing their focus on the provision of headquarters services. Relatedly, Bernard and Fort (2013) note the prevalence of factoryless manufacturing firms in the US, which they find primarily consist of firms that focus their activities on goods design while also coordinating the manufacture and assembly of products in (often) overseas locations. It is therefore possible that we are simply observing a trend toward more factoryless firms in the UK. It is important to note that these two phenomena may be distinct: whereas offshoring typically denotes the movement of intermediates production to overseas locations, factoryless firms are typically importing final goods from overseas. We therefore take two approaches in our exploration of this issue, described below. We also note that the possibility of either phenomena occurring does not undermine the goal of the paper, which is simply to estimate the relationship between goods trade liberalization and increased services provision on the part of UK firms, independent of the firm's motivations for the transition. It does, however, potentially add nuance to the story, as it addresses whether firms are simply ceasing goods production in the face of competition, or are relocating goods production.

First, we can directly test for increased provision of headquarter services by simply repeating regression (1) but, rather than using domestic services revenues as the dependent variable, we instead use the value of firms' exports of services to affiliated foreign entreprises. This value is independently recorded as a unique service type within the ITIS dataset, and should be associated with increasing production fragmentation within the firm. That is, if firms do indeed respond to goods trade liberalization by focusing their domestic activities on the provision of headquarters services, we should observe a positive correlation between import tariff reductions and services exports to affiliated entreprises (our proxy for headquarters service provision) ${ }^{43}$ Table 14 shows that there is no evidence for this hypothesis - goods tariff reductions actually seem to reduce exports of affiliate services although the coefficient is not statistically significant. ${ }^{44}$

\footnotetext{
${ }^{43}$ We construct exports of affiliate services by matching our regression sample (which is from the ARD) to the International Trade in Services Inquiry (ITIS). If a firm cannot be matched and reports zero services exports or zero services production in the ARD, we set affiliate exports for that firm to zero. There are also a few firms which report positive services exports in the ARD but cannot be matched to the ITIS; we drop these from our sample. (Results are similar if we set affiliate services exports for such firms to zero instead of dropping them.)

${ }^{44}$ In unreported results, we also estimated our most basic specification which only includes year fixed effects and the two import barrier variables (similar to column 1 of Table 4). Here, the coefficient
} 
As a further test of the specific role of offshoring (i.e., trade in intermediates) we add controls for intermediate input tariffs in our estimation of equation 1. (See Section 2 for a description of the construction of these tariffs.) Intuitively, if UK manufacturing firms offshore manufacturing input production and re-import intermediate inputs, the shift out of domestic goods production and into services should be made easier by lower tariffs on intermediates because this reduces the cost of importing intermediates. Results are reported in columns (3) and (4) of Table 14, where we find that the main results are virtually unchanged when these controls are included. Furthermore, the coefficient on intermediate input tariffs is negative as expected but statistically insignificant. ${ }^{45} \mathrm{We}$ conclude that a shift toward increased relative provision of headquarters services in response to trade liberalization is unlikely to have played a major role over our sample period. ${ }^{46}$

\section{Determinants of Firms' Response to Trade Liberalization}

We next estimate specification (2) in which relative firm-level service-to-goods revenues are still the dependent variable but goods import tariffs are now interacted with additional regressors - i.e., we allow for firm heterogeneity in the response to trade liberalization. As discussed, the aim of this exercise is to provide evidence for or against the mechanisms discussion in Section 3. Table 15 reports the results. Column (1) includes interaction terms between goods import tariffs and initial R\&D stocks (normalized by firm sales), initial physical capital stocks (also normalized by firm sales), and the initial firm average wage, respectively. ${ }^{47}$ In column (2), we use labor productivity instead of wages as a proxy

on manufacturing import tariffs was indeed negative and significant, although its magnitude was only around one fourth of the effect of import tariffs on total services sales. Once we include additional control variables and more restrictive sets of fixed effects, however, the import tariff regressor becomes insignificant.

${ }^{45}$ One explanation for this negative finding is that reduced intermediate input tariffs also have the additional effect of making intermediates imported from outside the firm's boundaries cheaper, hence lowering production cost. If this cost-reducing effect is stronger for goods than service production, lower input tariffs will induce a relative shift toward good production, partially offsetting the offshoring effect just discussed. Unfortunately, our data do not allow us to further quantify the relative importance of these two channels.

${ }^{46}$ In unreported results, we also implemented a version of the approach taken by Autor, et al (2014). In short, we explored the UK industry-level impact of Chinese import penetration, where we instrumented for Chinese import penetration with import penetration in non-UK high-income countries over our period, 1997-2007. We find results consistent with those reported here - i.e., relatively greater Chinese import penetration is associated with a relatively larger shift toward services across UK industries. These results are available upon request.

${ }^{47}$ We note that when we include R\&D stocks our sample shifts toward R\&D-intensive firms due to the fact that our source for the R\&D information, the BERD, samples firms that are relatively likely to engage in $\mathrm{R} \& \mathrm{D}$. 
for the skill-intensity of production and in column (3) we include both. ${ }^{48}$ In column (4), we further control for the initial share of services in total sales to account for the possibility that firms with higher initial service production might find the shift into services easier. Finally, column (5) adds 2-digit industry time trends.

Firstly, the results indicate a role for R\&D in promoting the firm's response to trade liberalization. The coefficient on the interaction term is negative and statistically significant throughout and is not much affected by the inclusion of additional control variables. Firms with higher initial R\&D stocks thus see a stronger shift into services relative to goods revenues as manufacturing import tariffs fall. At the same time, we find little impact on the transition to services from any of the other variables. A higher initial capital intensity is associated with a less pronounced transition but the effect is not statistically significant at conventional levels. In addition, if we take the initial average wage as a proxy for initial skill, it is clear that the most low-skill intensive firms are not necessarily the most responsive to the liberalization episode. This points away from the simple Heckscher-Ohlin channel discussed in Section 3. Having also ruled out the offshoring channel above, the evidence suggests a prominent role for the knowledge-intensity of the firm, as proxied by the R\&D stock, in driving the shift toward increased relative services provision in the face of trade liberalization.

It therefore seems that trade liberalization in the goods market leads firms to shift toward increased provision of services in the face of falling import barriers, and that the most expertise-intensive firms are the most responsive. This evidence seems to favor a mechanism by which accumulated expertise allows firms to shift into increased service provision. We note, however, that it is also consistent with a more nuanced HeckscherOhlin mechanism in which R\&D intensity itself is a source of comparative advantage. ${ }^{49}$

\section{Concluding Remarks}

In the face of trade liberalization domestic firms are often forced out of the market, whereas others adapt and survive. In this paper we have focused on a new channel of adaptation, namely the shift toward increased provision of services in lieu of goods production. Using firm-level data for the UK over the period 1997-2007, we have explored the link between lower manufacturing import tariffs and the firm's tradeoff between goods production and the provision of services, finding that lower import tariffs on goods caused

\footnotetext{
${ }^{48}$ As discussed previously, labor productivity might also play a role if the transition into services production requires a fixed cost investment. This investment would only be profitable for more productive firms and we should observe a stronger shift into services for such firms in response to the tariff reductions.

${ }^{49}$ In addition, to the extent that our proxy for skill is imprecise, our R\&D variable may also be picking up additional variation in skill across firms.
} 
firms to shift into services provision, and out of goods production. The magnitude of our results is highly significant, both statistically and economically. ${ }^{50}$

We also examined the factors influencing the extent of the transition into services. We found that a firm's initial stock of R\&D is strongly associated with a successful transition, while the average skill level of the firm (as proxied by average wages), its productivity, its capital stock and initial level of service production play little direct role. While we interpret this as evidence that a firm's accumulated expertise may be a key asset in surviving import competition, we note that this does not rule out a more nuanced Heckscher-Ohlin mechanism in which R\&D intensity itself is a source of comparative advantage.

\footnotetext{
${ }^{50}$ As a comparison to somewhat related work, Chatterjee, Dix-Carneiro and Vichyanond (2013) explore the response of multi-product firms to exchange rate shocks, finding a large response in terms of the number of products added in the face of an exchange rate depreciation.
} 


\section{References}

[1] Autor, D., D. Dorn, G. Hanson, and J. Song (2014) "Trade Adjustment: WorkerLevel Evidence" Quarterly Journal of Economics Vol. 129(4), pp. 1799-1860.

[2] Baines, T., H. Lightfoot, O. Benedettini, and J. Kay (2009) "The Servitization of Manufacturing" Journal of Manufacturing Technology Management Vol. 20(5), pp. 547-567.

[3] Bernard, A. B., Jensen, J. B., and Schott, P. K. (2006a), "Trade costs, firms and productivity", Journal of monetary Economics, 53(5), 917-937.

[4] Bernard, A. B., Jensen, J. B., and Schott, P. K. (2006b), "Survival of the best fit: Exposure to low-wage countries and the (uneven) growth of US manufacturing plants", Journal of international Economics, 68(1), 219-237.

[5] Bernard, Andrew B. and Teresa C. Fort (2013) "Factoryless Goods Producers in the US" NBER Working Paper No. 19396.

[6] Bernard, Andrew B., Valerie Smeets, and Frederic Warzynski (2017) "Rethinking deindustrialization." Economic Policy 32(89), 5-38.

[7] Bloom, N., Draca, M., and Van Reenen, J. (2016), "Trade induced technical change? The impact of Chinese imports on innovation, IT and productivity", The Review of Economic Studies, 83(1), 87-117.

[8] Bloom, N., R. Griffith, and J. Van Reenen (2002) "Do R\&D tax credits work? Evidence from a panel of countries 1979-1997” , Journal of Public Economics, Vol. 85(1), $1-31$.

[9] Bloom, N., R. Sadun, and J. Van Reenen (2010) "Does Product Market Competition Lead Firms to Decentralize?" American Economic Review Papers and Proceedings, Vol. 100(3), 434-438.

[10] Bloom, N., P. Romer, S. Terry, and J. Van Reenen (2012) "A Trapped Factors Model of Innovation", American Economic Review Papers and Proceedings, Vol. 103(3), 208-213.

[11] Breinlich, H., and C. Criscuolo (2010) "International Trade in Services: A Portrait of Importers and Exporters", Journal of International Economics, Vol. 84(2). 
[12] Bustos, P. (2011), "Trade Liberalization, Exports and Technology Upgrading: Evidence on the Impact of MERCOSUR on Argentinean Firms", American Economic Review, 101(1), 304-40.

[13] Cameron, A. C., and Trivedi, P. K. (2013), "Regression analysis of count data (Vol. 53)", Cambridge university press.

[14] Chatterjee, Arpita, Rafael Dix-Carneiro, and Jade Vichyanond. " Multi-product firms and exchange rate fluctuations." American Economic Journal: Economic Policy 5.2 (2013): 77-110.

[15] Crinò, Rosario (2009) "Offshoring, multinationals and labour market: a review of the empirical literature." Journal of Economic Surveys, Vol. 23(2), pp. 197-249.

[16] Criscuolo, C., J. Haskel, and R. Martin (2003) "Import Competition, Productivity and Restructuring in UK Manufacturing" , Oxford Review of Economic Policy, Vol. 20(3), pp. 393-408.

[17] Crozet, M. and E. Milet (2016) "The Servitization of French Manufacturing Firms", in L. Fontagne and A. Harrison, The Factory Free Economy, Oxford University Press.

[18] Crozet, M., and Trionfetti, F. (2013), "Firm-level comparative advantage", Journal of International Economics, 91(2), 321-328.

[19] Feenstra, Robert C. and John Romalis (2014), "International Prices and Endogenous Quality" Quarterly Journal of Economics, Vol. 129(2), pp. 477-527.

[20] Francois, Joseph and Bernard Hoekman (2010), "Services Trade and Policy." Journal of Economic Literature, 48: 642-692.

[21] Griliches, Zvi (1979) "Issues in Assessing the Contribution of Research and Development to Productivity Growth" , Bell Journal of Economics, 10(1), 92-116.

[22] Grossman, G. M., and Rossi-Hansberg, E. (2008). "Trading tasks: A simple theory of offshoring", The American Economic Review, 98(5), 1978-1997.

[23] Head, Keith, and Thierry Mayer (2013) "Gravity equations: Workhorse, toolkit, and cookbook." chapter to appear in the Handbook of International Economics Vol. 4, eds. Gopinath, Helpman, and Rogoff.

[24] Khandelwal (2010) "The Long and Short (of) Quality Ladders" Review of Economic Studies, Vol. 77(4), pp. 1450-1476. 
[25] Kneller, Richard, and Danny McGowan (2012) "Tax policy and firm entry and exit dynamics: Evidence from OECD countries." University of Nottingham Discussion Papers in Economics, 12/01.

[26] Lileeva, A., and Trefler, D. (2010), "Improved access to foreign markets raises plantlevel productivity? for some plants", The Quarterly Journal of Economics, 125(3), 1051-1099.

[27] Liu, R. (2010) "Import Competition and Firm Refocusing" , Canadian Journal of Economics, Vol. 43(2), pp. 440-466.

[28] Mayer, Melitz and Ottaviano (2014) "Market Size, Competition and the Product Mix of Exporters", American Economic Review, Vol. 104(2), pp. 495-536.

[29] Neely, A. (2011). "The Servitization of Manufacturing: Further Evidence" , Paper presented at the 18th European Operations Management Association Conference, Cambridge.

[30] Office for National Statistics (2007a) "Consumer Trends, Quarter 4 2007" , Ed: Ann Harris, Office for National Statistics: London.

[31] Office for National Statistics (2007b). United Kingdom Balance of Payments 2007.

[32] Office for National Statistics (2012). United Kingdom Input-Output Analytical Tables, 1995.

[33] Office for National Statistics, Annual Respondents Database, 1973-2008: Secure Access [computer file]. 3rd Edition. Colchester, Essex: UK Data Archive [distributor], June 2012. SN: 6644, http://dx.doi.org/10.5255/UKDA-SN-6644-5.

[34] Office for National Statistics, Business Expenditure on Research and Development, 1994-2012: Secure Access [computer file]. 3rd Edition. Colchester, Essex: UK Data Archive [distributor], January 2014. SN: 6690 , http://dx.doi.org/10.5255/UKDASN-6690-3.

[35] Office for National Statistics, International Trade in Services, 1996-2012: Secure Access [computer file]. 3rd Edition. Colchester, Essex: UK Data Archive [distributor], July 2014. SN: 6711, http://dx.doi.org/10.5255/UKDA-SN-6711-3.

[36] Partington, J. 2001, "The launch of the annual business inquiry", Labour Market Trends, 109 (5): 25 ?68. 
[37] Pavcnik, N. (2002), "Trade liberalization, exit, and productivity improvements: Evidence from Chilean plants", The Review of Economic Studies, 69(1), 245-276.

[38] Rodriguez, F., and Rodrik, D. (2000), "Trade policy and economic growth: a skeptic's guide to the cross-national evidence", NBER macroeconomics annual, 15, 261-325.

[39] Santos-Silva, J.S.S., and S. Tenreyo (2006) "The Log of Gravity" , Review of Economics and Statistics, Vol. 88(4), pp. 641-658.

[40] Shepherd, Dean and Johan Wiklund (2003) "Knowledge-Based Resources, Entrepreneurial Orientation, and the Performance of Small and Medium-Sized Businesses", Strategic Management Journal, Vol. 24, pp. 1307-1314.

[41] Teshima (2010) "Import Competition and Innovation at the Plant Level: Evidence from Mexico", mimeo.

[42] Trefler, D. (2004), "The long and short of the Canada-US free trade agreement", The American Economic Review, 94(4), 870-895.

[43] Wright, Greg C. (2014). "Revisiting the employment impact of offshoring", European Economic Review, 66, 63-83. 


\section{Tables and Figures}

Figure 1: Share of Services in UK Manufacturing (1997-2007)

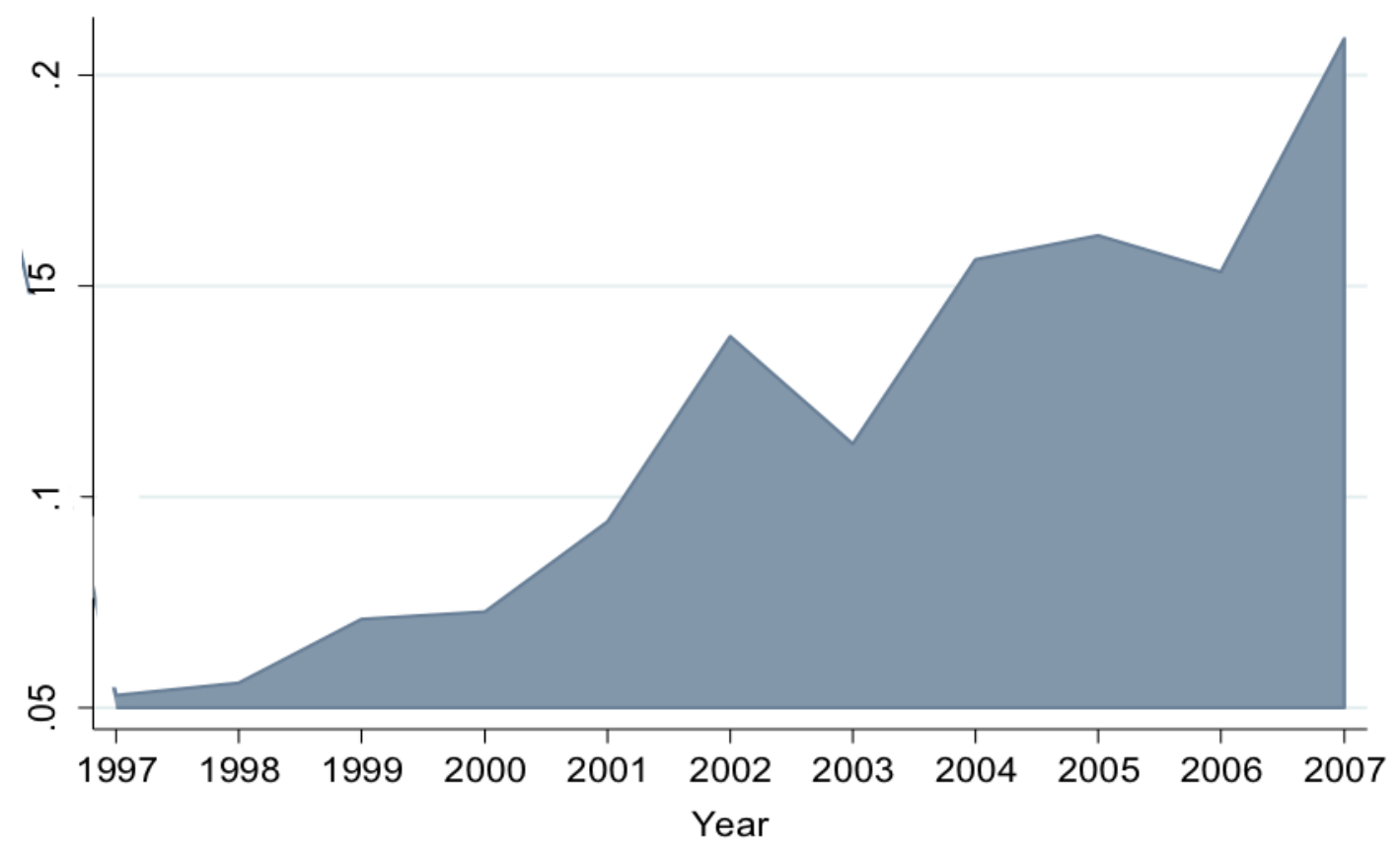

Notes: Figure shows the ratio of services revenues to total revenues in the UK manufacturing sector over the period 1997 to 2007. See Section 2 for details on the underlying data. 
Figure 2: Average Annual Within-Firm Growth in Goods versus Services

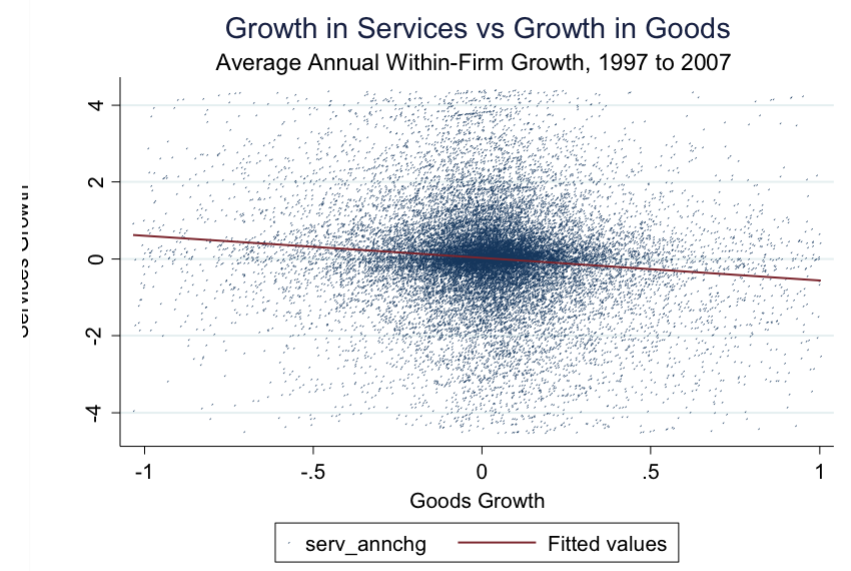

Notes: Figure plots the average annual log change in Goods production versus Services provision within firms in the UK manufacturing sector over the period 1997-2007. See Section 2 for details on the underlying data.

Table 1: Services Types Exported by UK Manufacturing Firms

\begin{tabular}{lcc}
\hline & \multicolumn{2}{c}{ Enterprise-Years } \\
\cline { 2 - 3 } Service Type & Fraction & Number \\
\hline Royalties and Licenses & $38 \%$ & 1890 \\
Technical Services & $36 \%$ & 1787 \\
Agricultural, Mining, On-Site Processing Services & $20 \%$ & 986 \\
Business and Professional Services & $18 \%$ & 890 \\
Communications Services & $11 \%$ & 542 \\
Computer and Information Services & $8 \%$ & 382 \\
Merchanting and Other Trade-Related Services & $8 \%$ & 378 \\
Other Trade in Services & $3 \%$ & 169 \\
Personal, Cultural and Recreational Services & $2 \%$ & 86 \\
Construction Services & $2 \%$ & 79 \\
Insurance Services & $1 \%$ & 25 \\
\hline
\end{tabular}

Notes: The table presents the fraction and number of firm-years for which we observe exports of each services category. Fractions are calculated relative to the total number of firm-year observations in our regression sample which can be matched to the ITIS (4,932 observations in total). Firms can export more than one service in a given year, so that percentages add up to more than 100 percent. See Section 2 for details on the underlying data. 
Table 2: Firm Entry and Exit

\begin{tabular}{|c|c|c|c|c|c|c|c|}
\hline \multirow[b]{2}{*}{ Year } & \multirow[b]{2}{*}{ Firms } & \multicolumn{2}{|c|}{ Entrants } & \multicolumn{2}{|c|}{ Exiters } & \multicolumn{2}{|c|}{ Stayers } \\
\hline & & Count & Fraction & Count & Fraction & Count & Fraction \\
\hline 1997 & 11086 & 11086 & $100 \%$ & 5453 & $49 \%$ & - & - \\
\hline 1998 & 11386 & 5753 & $51 \%$ & 5621 & $49 \%$ & 3737 & $33 \%$ \\
\hline 1999 & 11161 & 5396 & $48 \%$ & 5568 & $50 \%$ & 3164 & $28 \%$ \\
\hline 2000 & 10974 & 5381 & $49 \%$ & 5482 & $50 \%$ & 3196 & $29 \%$ \\
\hline 2001 & 11457 & 5965 & $52 \%$ & 5812 & $51 \%$ & 3082 & $27 \%$ \\
\hline 2002 & 10541 & 4896 & $46 \%$ & 5226 & $50 \%$ & 3280 & $31 \%$ \\
\hline 2003 & 10307 & 4992 & $48 \%$ & 5013 & $49 \%$ & 3151 & $31 \%$ \\
\hline 2004 & 10020 & 4726 & $47 \%$ & 5064 & $51 \%$ & 3019 & $30 \%$ \\
\hline 2005 & 9417 & 4461 & $47 \%$ & 5035 & $53 \%$ & 2596 & $28 \%$ \\
\hline 2006 & 8587 & 4205 & $49 \%$ & 4171 & $49 \%$ & 2602 & $30 \%$ \\
\hline 2007 & 9448 & 5032 & $53 \%$ & 9448 & $100 \%$ & - & - \\
\hline
\end{tabular}

Notes: The total number of firms in the full data are reported along with their persistence in the sample. Entrants are firms that were not in the sample in the prior period but are in the sample in the current period. Exiters are firms that are in the sample in the current period but are not in the sample in the following period. Stayers are firms that are in the sample in the prior, current and following period. The fraction is the percentage of total firms in each category - a firm only present in the current period will be both an exiter and an entrant so our fractions need not sum to 100 percent.

Table 3: Change in Services Share and Beginning-of-Period Firm-Level Covariates

\begin{tabular}{|c|c|c|c|c|c|}
\hline \multirow[b]{2}{*}{ Variables } & \multicolumn{5}{|c|}{$\Delta$ Ratio of Services/Goods Revenue } \\
\hline & (1) & $(2)$ & $(3)$ & $(4)$ & $(5)$ \\
\hline $\log$ (Initial avg. wage) & $\begin{array}{l}0.00093^{\text {*** }} \\
(0.00050)\end{array}$ & & & & $\begin{array}{c}-0.00175 \\
(0.00142)\end{array}$ \\
\hline $\log ($ Initial R\&D) & & $\begin{array}{l}0.00091^{* * *} \\
(0.00027)\end{array}$ & & & $\begin{array}{l}0.00099^{* * *} \\
(0.00031)\end{array}$ \\
\hline $\log ($ Initial capital stock $)$ & & & $\begin{array}{c}-0.00013 \\
(0.00016)\end{array}$ & & $\begin{array}{c}-0.00051 \\
(0.00036)\end{array}$ \\
\hline $\log ($ Initial total revenue) & & & & $\begin{array}{l}0.00042^{* * *} \\
(0.00012)\end{array}$ & $\begin{array}{c}0.00014 \\
(0.00041)\end{array}$ \\
\hline Observations & 60880 & 15346 & 64160 & 64160 & 14644 \\
\hline Firms & 22430 & 5007 & 23166 & 23166 & 4895 \\
\hline R-squared & 0.000 & 0.001 & 0.000 & 0.000 & 0.001 \\
\hline
\end{tabular}

Notes: Table presents results for regressions of the annual percentage-point change in the share of services in total revenue (denoted $\Delta$ Ratio of Services/Goods Revenue) on the firm-level variables listed in the first column. Firm-level variables are measured at the beginning of the period over which the change in the dependent variable is calculated. See Section 2 for details on the underlying data. Standard errors clustered at the industry level and are in parentheses, where ${ }^{*} \mathrm{p}<0.10,{ }^{* *} \mathrm{p}<0.05$, $* * * \mathrm{p}<0.01$ 
Table 4: Baseline Results

\begin{tabular}{|c|c|c|c|c|c|c|c|}
\hline \multirow[b]{2}{*}{ Variables } & \multicolumn{7}{|c|}{ Ratio of Service/Goods Revenue } \\
\hline & (1) & $(2)$ & (3) & (4) & $(5)$ & (6) & (7) \\
\hline Goods import tariffs & $\begin{array}{c}-0.916^{* * *} \\
(0.306)\end{array}$ & $\begin{array}{c}-0.893^{* * *} \\
(0.329)\end{array}$ & $\begin{array}{c}-0.859^{* * *} \\
(0.328)\end{array}$ & $\begin{array}{c}-0.141^{* * *} \\
(0.063)\end{array}$ & $\begin{array}{c}-0.184^{* * *} \\
(0.062)\end{array}$ & $\begin{array}{c}-0.209^{* * *} \\
(0.064)\end{array}$ & $\begin{array}{c}-0.217^{* * *} \\
(0.066)\end{array}$ \\
\hline Goods export tariffs & & $\begin{array}{c}-0.148 \\
(0.132)\end{array}$ & $\begin{array}{c}-0.147 \\
(0.125)\end{array}$ & $\begin{array}{c}0.010 \\
(0.139)\end{array}$ & $\begin{array}{c}-0.038 \\
(0.045)\end{array}$ & $\begin{array}{c}-0.052 \\
(0.047)\end{array}$ & $\begin{array}{c}-0.051 \\
(0.047)\end{array}$ \\
\hline Services export barriers & & $\begin{array}{c}0.129 \\
(0.142)\end{array}$ & $\begin{array}{c}0.140 \\
(0.134)\end{array}$ & $\begin{array}{l}2.701^{* * *} \\
(1.274)\end{array}$ & $\begin{array}{c}0.015 \\
(0.090)\end{array}$ & $\begin{array}{c}0.040 \\
(0.086)\end{array}$ & $\begin{array}{c}0.119 \\
(0.092)\end{array}$ \\
\hline Services import barriers & $\begin{array}{c}0.945 \\
(0.611)\end{array}$ & $\begin{array}{l}1.115^{*} \\
(0.597)\end{array}$ & $\begin{array}{c}0.971^{*} \\
(0.577)\end{array}$ & $\begin{array}{c}4.207 \\
(4.469)\end{array}$ & $\begin{array}{c}-0.625 \\
(1.118)\end{array}$ & $\begin{array}{c}-0.210 \\
(1.047)\end{array}$ & $\begin{array}{c}-0.835 \\
(1.248)\end{array}$ \\
\hline $\log$ (Labor productivity) & & & $\begin{array}{c}0.114 \\
(0.239)\end{array}$ & $\begin{array}{c}-0.005 \\
(0.204)\end{array}$ & & $\begin{array}{c}-0.275 \\
(0.228)\end{array}$ & $\begin{array}{c}-0.272 \\
(0.227)\end{array}$ \\
\hline $\log$ (Average wage) & & & $\begin{array}{l}0.146^{* * *} \\
(0.067)\end{array}$ & $\begin{array}{c}-0.017 \\
(0.094)\end{array}$ & & $\begin{array}{l}0.957^{* * *} \\
(0.359)\end{array}$ & $\begin{array}{l}0.954^{* * *} \\
(0.359)\end{array}$ \\
\hline Year FEs & Yes & Yes & Yes & Yes & Yes & Yes & Yes \\
\hline Industry FEs & No & No & No & Yes & No & No & No \\
\hline Firm FEs & No & No & No & No & Yes & Yes & Yes \\
\hline Time Trends & No & No & No & No & No & No & Yes \\
\hline Observations & 109598 & 107073 & 97502 & 97502 & 60416 & 54905 & 54905 \\
\hline Number of Firms & 46164 & 45232 & 40948 & 40948 & 15525 & 14284 & 14284 \\
\hline $\begin{array}{l}\text { Notes: PPML regression } \\
\text { the log of firm producti } \\
\text { 2-digit UK SIC industry } \\
\text { Trade in Services Inquir } \\
* \mathrm{p}<0.10,{ }^{* *} \mathrm{p}<0.05, * *\end{array}$ & $\begin{array}{l}\text { the ratio } \\
\text { and the } \\
\text { e trends } \\
\text { CIS). Sta } \\
0.01 \text {. }\end{array}$ & $\begin{array}{l}\text { firm's re } \\
\text { average } \\
\text { ta Source } \\
\text { d errors }\end{array}$ & $\begin{array}{l}\text { es from } \\
\text { FEs i } \\
\text { NS Ann } \\
\text { lusterec }\end{array}$ & $\begin{array}{l}\text { ices and } \\
\text { ate fixed } \\
\text { Responde } \\
\text { the indus }\end{array}$ & $\begin{array}{l}\text { nues fron } \\
\text { ects in th } \\
\text { Databas } \\
\text { level ans }\end{array}$ & $\begin{array}{l}\text { ods on inc } \\
\text { odel. Tin } \\
\text { RD) and } \\
\text { in paren }\end{array}$ & $\begin{array}{l}\text { y tariffs, } \\
\text { ends are } \\
\text { national } \\
\text { s, where }\end{array}$ \\
\hline
\end{tabular}

Table 5: Services Revenues as Dependent Variable

\begin{tabular}{|c|c|c|c|c|c|c|c|}
\hline \multirow[b]{2}{*}{ Variables } & \multicolumn{7}{|c|}{ Services revenue } \\
\hline & (1) & (2) & (3) & (4) & (5) & (6) & (7) \\
\hline Goods import tariffs & $\begin{array}{c}-0.597^{* * *} \\
(0.227)\end{array}$ & $\begin{array}{c}-0.478^{* *} \\
(0.212)\end{array}$ & $\begin{array}{r}-0.319^{*} \\
(0.167)\end{array}$ & $\begin{array}{r}-0.013 \\
(0.017)\end{array}$ & $\begin{array}{c}-0.025^{* *} \\
(0.012)\end{array}$ & $\begin{array}{c}-0.024^{* *} \\
(0.011)\end{array}$ & $\begin{array}{c}-0.026^{* *} \\
(0.012)\end{array}$ \\
\hline Goods export tariffs & & $\begin{array}{c}-0.275 \\
(0.253)\end{array}$ & $\begin{array}{c}-0.154 \\
(0.123)\end{array}$ & $\begin{array}{c}0.015 \\
(0.071)\end{array}$ & $\begin{array}{c}-0.116^{* *} \\
(0.048)\end{array}$ & $\begin{array}{c}-0.093^{* *} \\
(0.046)\end{array}$ & $\begin{array}{c}-0.095^{* *} \\
(0.047)\end{array}$ \\
\hline Services export barriers & & $\begin{array}{c}-0.720 \\
(1.513)\end{array}$ & $\begin{array}{r}-0.160 \\
(0.429)\end{array}$ & $\begin{array}{c}0.082 \\
(0.095)\end{array}$ & $\begin{array}{c}0.133 \\
(0.099)\end{array}$ & $\begin{array}{c}0.113 \\
(0.082)\end{array}$ & $\begin{array}{c}0.133 \\
(0.082)\end{array}$ \\
\hline Services import barriers & $\begin{array}{l}2.526^{* * *} \\
(0.823)\end{array}$ & $\begin{array}{l}2.598^{* *} \\
(1.009)\end{array}$ & $\begin{array}{l}2.551^{* * *} \\
(0.742)\end{array}$ & $\begin{array}{l}4.281^{* * *} \\
(1.323)\end{array}$ & $\begin{array}{c}0.499 \\
(0.597)\end{array}$ & $\begin{array}{c}0.632 \\
(0.426)\end{array}$ & $\begin{array}{c}0.711 \\
(0.450)\end{array}$ \\
\hline $\log$ (Labor productivity) & & & $\begin{array}{c}0.429^{* *} \\
(0.176)\end{array}$ & $\begin{array}{l}0.522^{* * *} \\
(0.193)\end{array}$ & & $\begin{array}{l}0.206^{* * *} \\
(0.070)\end{array}$ & $\begin{array}{l}0.193^{* * *} \\
(0.069)\end{array}$ \\
\hline $\log$ (Average wage) & & & $\begin{array}{l}1.177^{* * *} \\
(0.081)\end{array}$ & $\begin{array}{l}0.977^{* * *} \\
(0.039)\end{array}$ & & $\begin{array}{l}0.403^{* * *} \\
(0.137)\end{array}$ & $\begin{array}{l}0.395^{* * *} \\
(0.135)\end{array}$ \\
\hline Year FEs & Yes & Yes & Yes & Yes & Yes & Yes & Yes \\
\hline Industry FEs & No & No & No & Yes & No & No & No \\
\hline Firm FEs & No & No & No & No & Yes & Yes & Yes \\
\hline Time Trends & No & No & No & No & No & No & Yes \\
\hline Observations & 114006 & 111436 & 101383 & 101383 & 58192 & 56782 & 56782 \\
\hline Number of Firms & 47919 & 46937 & 42480 & 42480 & 15939 & 14709 & 14709 \\
\hline $\begin{array}{l}\text { Notes: PPML regression } \\
\text { the log average wage. } \\
\text { trends. Data Source: O } \\
\text { (ITIS). Standard errors } \\
\text { p }<0.01 \text {. }\end{array}$ & lusterec & Dind & . & 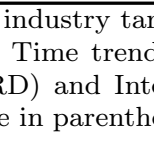 & the 1 & $\begin{array}{l}\text { irm proc } \\
\text { K SIC i } \\
\text { e in Ser } \\
<0.10, * *\end{array}$ & $\begin{array}{l}\text { vity, and } \\
\text { try time } \\
\text { Inquiry } \\
.05, * * *\end{array}$ \\
\hline
\end{tabular}


Table 6: Goods Revenues as Dependent Variable

\begin{tabular}{|c|c|c|c|c|c|c|c|}
\hline \multirow[b]{2}{*}{ Variables } & \multicolumn{7}{|c|}{ Goods revenue } \\
\hline & (1) & $(2)$ & (3) & $(4)$ & $(5)$ & (6) & $(7)$ \\
\hline Goods import tariffs & $\begin{array}{l}0.059^{* * *} \\
(0.012)\end{array}$ & $\begin{array}{c}0.023^{*} \\
(0.014)\end{array}$ & $\begin{array}{c}0.007 \\
(0.005)\end{array}$ & $\begin{array}{l}0.004^{* *} \\
(0.002)\end{array}$ & $\begin{array}{l}0.000 \\
(0.002)\end{array}$ & $\begin{array}{c}0.000 \\
(0.003)\end{array}$ & $\begin{array}{c}-0.002 \\
(0.002)\end{array}$ \\
\hline Goods export tariffs & & $\begin{array}{l}0.079^{* * *} \\
(0.016)\end{array}$ & $\begin{array}{l}0.029^{* * *} \\
(0.010)\end{array}$ & $\begin{array}{c}0.011 \\
(0.011)\end{array}$ & $\begin{array}{c}-0.002 \\
(0.091)\end{array}$ & $\begin{array}{c}0.003 \\
(0.005)\end{array}$ & $\begin{array}{c}0.003 \\
(0.006)\end{array}$ \\
\hline Services export barriers & & $\begin{array}{c}-0.006 \\
(0.062)\end{array}$ & $\begin{array}{c}0.011 \\
(0.042)\end{array}$ & $\begin{array}{r}-0.033^{*} \\
(0.019)\end{array}$ & $\begin{array}{c}-0.022 \\
(0.051)\end{array}$ & $\begin{array}{c}-0.023 \\
(0.015)\end{array}$ & $\begin{array}{r}-0.025^{*} \\
(0.014)\end{array}$ \\
\hline Services import barriers & $\begin{array}{c}0.373^{*} \\
(0.221)\end{array}$ & $\begin{array}{c}0.322 \\
(0.228)\end{array}$ & $\begin{array}{c}0.105 \\
(0.104)\end{array}$ & $\begin{array}{c}0.015 \\
(0.233)\end{array}$ & $\begin{array}{l}0.141^{* *} \\
(0.053)\end{array}$ & $\begin{array}{l}0.111^{* *} \\
(0.045)\end{array}$ & $\begin{array}{l}0.099^{* *} \\
(0.046)\end{array}$ \\
\hline $\log$ (Labor productivity) & & & $\begin{array}{l}0.316^{* * *} \\
(0.055)\end{array}$ & $\begin{array}{l}0.352^{* * *} \\
(0.045)\end{array}$ & & $\begin{array}{l}0.170^{* * *} \\
(0.026)\end{array}$ & $\begin{array}{l}0.168^{* * *} \\
(0.023)\end{array}$ \\
\hline $\log$ (Average wage) & & & $\begin{array}{l}0.978^{* * *} \\
(0.026)\end{array}$ & $\begin{array}{l}0.956^{* * *} \\
(0.015)\end{array}$ & & $\begin{array}{l}0.700^{* * *} \\
(0.031)\end{array}$ & $\begin{array}{l}0.699^{* * *} \\
(0.031)\end{array}$ \\
\hline Year FEs & Yes & Yes & Yes & Yes & Yes & Yes & Yes \\
\hline Industry FEs & No & No & No & Yes & No & No & No \\
\hline Firm FEs & No & No & No & No & Yes & Yes & Yes \\
\hline Time Trends & No & No & No & No & No & No & Yes \\
\hline Observations & 113127 & 110557 & 100608 & 100608 & 81277 & 78983 & 78983 \\
\hline Number of Firms & 47594 & 46648 & 42199 & 42199 & 23024 & 21128 & 21128 \\
\hline
\end{tabular}

Table 7: Relating Services Relative to Goods Sales with Firm Outcomes

\begin{tabular}{lcccccc}
\hline & $\begin{array}{c}\text { Total } \\
\text { Sales }\end{array}$ & $\begin{array}{c}\text { Average } \\
\text { Wage }\end{array}$ & $\begin{array}{c}\text { Employment } \\
\text { ARD }\end{array}$ & $\begin{array}{c}\text { Labor } \\
\text { Productivity }\end{array}$ & $\begin{array}{c}5-y e a r \\
\text { Exit Rate }\end{array}$ \\
\cline { 2 - 6 } & $(1)$ & $(2)$ & $(3)$ & $(4)$ & $(5)$ \\
\hline Log(Ratio Service/Goods production) & $\begin{array}{c}0.080^{* * *} \\
(0.029)\end{array}$ & $\begin{array}{c}0.028^{* * *} \\
(0.003)\end{array}$ & $\begin{array}{c}0.092^{* * *} \\
(0.023)\end{array}$ & $\begin{array}{c}0.024^{* * *} \\
(0.004)\end{array}$ & $\begin{array}{c}0.001 \\
(0.003)\end{array}$ \\
\hline Predicted Effect of a 1\% Tariff Reduction & $3.99 \%$ & $1.38 \%$ & $4.61 \%$ & $1.20 \%$ & $0.00 \%$ \\
\hline Observations & 48638 & 43324 & 43533 & 43533 & 48638 \\
\hline
\end{tabular}

Notes: Year and firm fixed effects included. Data Source: ONS Annual Respondents Database (ARD).

Standard errors are clustered at the industry level and are in parentheses, where ${ }^{*} \mathrm{p}<0.10,{ }^{* *} \mathrm{p}<0.05$, ${ }^{* * *}$ $\mathrm{p}<0.01$. 
Table 8: Baseline Robustness - Ratio of Service to Total Revenue

\begin{tabular}{lcc}
\hline & \multicolumn{2}{c}{ Ratio of Service/ } \\
Variables & $(1)$ & $(2)$ \\
\cline { 2 - 3 } Goods import tariffs & $-0.028^{* * *}$ & $-0.030^{* * *}$ \\
Goods export tariffs & $(0.009)$ & $(0.009)$ \\
& $-0.036^{* * *}$ & $-0.034^{* *}$ \\
Services export barriers & $(0.013)$ & $(0.014)$ \\
& -0.003 & 0.030 \\
Services import barriers & $(0.044)$ & $(0.041)$ \\
& 0.381 & 0.356 \\
log(Labor productivity) & -0.019 & $(0.255)$ \\
& $(0.041)$ & -0.022 \\
log(Average wage) & $-0.128^{*}$ & $-0.040)$ \\
& $(0.071)$ & $(0.069)$ \\
\hline Year FEs & Yes & Yes \\
Industry FEs & No & No \\
Firm FEs & Yes & Yes \\
Time Trends & No & Yes \\
\hline Observations & 55590 & 55590 \\
Number of firms & 14466 & 14466 \\
\hline Notes & &
\end{tabular}

Notes: PPML regressions of the ratio of a firm's revenues from services and revenues from goods on industry tariffs, the log of firm productivity, and the log average wage. FEs indicate fixed effects in the model. Time trends are 2-digit UK SIC industry time trends. Data Source: ONS Annual Respondents Database (ARD) and International Trade in Services Inquiry (ITIS). Standard errors are clustered at the industry level and are in parentheses, where ${ }^{*} \mathrm{p}<0.10,{ }^{* *} \mathrm{p}<0.05,{ }^{* * *} \mathrm{p}<0.01$. 
Table 9: Baseline Robustness - OLS

\begin{tabular}{lcccccc}
\hline & \multicolumn{5}{c}{ Ratio of Service/Goods Revenue } \\
\cline { 2 - 6 } Variables & $(1)$ & $(2)$ & $(3)$ & $(4)$ & $(5)$ & $(6)$ \\
\hline Goods import tariffs & $-0.027^{* * *}$ & $-0.021^{* * *}$ & $-0.020^{* * *}$ & -0.004 & $-0.012^{*}$ & $-0.013^{* *}$ \\
& $(0.005)$ & $(0.005)$ & $(0.005)$ & $(0.005)$ & $(0.009)$ & $(0.006)$ \\
Goods export tariffs & & -0.019 & -0.019 & 0.007 & -0.005 & -0.007 \\
& & $(0.010)$ & $(0.010)$ & $(0.016)$ & $(0.007)$ & $(0.014)$ \\
Services export barriers & & 0.003 & 0.004 & 0.065 & 0.001 & 0.001 \\
Services import barriers & $0.107^{* * *}$ & $(0.023)$ & $(0.023)$ & $(0.083)$ & $(0.002)$ & $(0.033)$ \\
& $(0.030)$ & $(0.029)$ & $(0.028)$ & $(0.354)$ & $(0.031)$ & $(0.104)$ \\
log(Labor productivity) & & & 0.020 & 0.004 & -0.019 & -0.019 \\
log(Average wage) & & $(0.021)$ & $(0.025)$ & $(0.018)$ & $(0.025)$ \\
& & & 0.022 & -0.002 & 0.064 & 0.064 \\
& & & $(0.009)$ & $(0.010)$ & $(0.034)$ & $(0.036)$ \\
\hline Year FEs & Yes & Yes & Yes & Yes & Yes & Yes \\
Industry FEs & No & No & No & Yes & No & No \\
Firm FEs & No & No & No & No & Yes & Yes \\
Time Trends & No & No & No & No & No & Yes \\
\hline Observations & 109598 & 107073 & 97502 & 97502 & 79160 & 79160 \\
Number of Firms & 46164 & 45232 & 40948 & 24578 & 22606 & 22606 \\
\hline Notes: OLS regra
\end{tabular}

Notes: OLS regressions of the ratio of a firm's revenues from services and revenues from goods on industry tariffs, the log of firm productivity, and the log average wage. FEs indicate fixed effects in the model. Time trends are 2-digit UK SIC industry time trends. Data Source: ONS Annual Respondents Database (ARD) and International Trade in Services Inquiry (ITIS). Standard errors are clustered at the industry level and are in parentheses, where ${ }^{*} \mathrm{p}<0.10,{ }^{* *} \mathrm{p}<0.05,{ }^{* * *} \mathrm{p}<0.01$. 
Table 10: Baseline Robustness - Import Penetration

\begin{tabular}{lcc}
\hline & \multicolumn{2}{c}{ Ratio of Service/Goods Revenue } \\
\cline { 2 - 3 } Variables & $(1)$ & $(2)$ \\
\hline Import Penetration & $1.429^{* *}$ & $1.431^{* *}$ \\
Goods export tariffs & $(0.724)$ & $(0.724)$ \\
& $-0.148^{* *}$ & $-0.149^{* *}$ \\
Services export barriers & $(0.064)$ & $(0.064)$ \\
Services import barriers & 0.006 & 0.005 \\
& -0.419 & $(0.237)$ \\
Log(Labor productivity) & $(0.673)$ & -0.424 \\
& -0.406 & $(0.675)$ \\
Log(Wage) & $(0.306)$ & -0.406 \\
& $0.842^{* *}$ & $(0.306)$ \\
& $(0.356)$ & $\left(0.842^{* *}\right.$ \\
\hline Year FEs & Yes & No \\
Industry FEs & No & No \\
Firm FEs & Yes & No \\
Time Trends & No & Yes \\
\hline Observations & 31573 & 31573 \\
Number of firms & 8213 & 8213 \\
\hline Notes: PPML regressions of the ratio of a firm's revenues
\end{tabular}

Notes: PPML regressions of the ratio of a firm's revenues from services and revenues from goods on goods import penetration, industry tariffs, the log of firm productivity, and the log average wage. FEs indicate fixed effects in the model. Time trends are 2-digit UK SIC industry time trends. Data Source: ONS Annual Respondents Database (ARD) and International Trade in Services Inquiry (ITIS). Standard errors are clustered at the industry level and are in parentheses, where ${ }^{*} \mathrm{p}<0.10,{ }^{* *} \mathrm{p}<0.05, * * * \mathrm{p}<0.01$. 
Table 11: Using Domestic Services Revenues in the Construction of the Revenue Ratio

\begin{tabular}{|c|c|c|c|c|}
\hline \multirow[b]{2}{*}{ Variables } & \multicolumn{2}{|c|}{ Ratio of Service/Goods Revenue } & \multicolumn{2}{|c|}{ Domestic Services Revenue } \\
\hline & (1) & $(2)$ & $(3)$ & $(4)$ \\
\hline Goods import tariffs & $\begin{array}{c}-0.248^{* * *} \\
(0.078)\end{array}$ & $\begin{array}{c}-0.253^{* * *} \\
(0.079)\end{array}$ & $\begin{array}{c}-0.085^{* * *} \\
(0.027)\end{array}$ & $\begin{array}{c}-0.087^{* * *} \\
(0.025)\end{array}$ \\
\hline Goods export tariffs & $\begin{array}{c}-0.129 \\
(0.080)\end{array}$ & $\begin{array}{c}-0.126 \\
(0.081)\end{array}$ & $\begin{array}{c}-0.092 \\
(0.061)\end{array}$ & $\begin{array}{c}-0.092 \\
(0.065)\end{array}$ \\
\hline Services export barriers & $\begin{array}{c}0.113 \\
(0.233)\end{array}$ & $\begin{array}{c}0.167 \\
(0.169)\end{array}$ & $\begin{array}{r}-0.028 \\
(0.168)\end{array}$ & $\begin{array}{r}-0.006 \\
(0.166)\end{array}$ \\
\hline Services import barriers & $\begin{array}{r}-0.349 \\
(0.798)\end{array}$ & $\begin{array}{r}-0.889 \\
(0.807)\end{array}$ & $\begin{array}{c}-0.111 \\
(0.398)\end{array}$ & $\begin{array}{r}-0.218 \\
(0.534)\end{array}$ \\
\hline $\log ($ Labor productivity) & $\begin{array}{r}-0.172 \\
(0.231)\end{array}$ & $\begin{array}{c}-0.171 \\
(0.231)\end{array}$ & $\begin{array}{c}0.016 \\
(0.123)\end{array}$ & $\begin{array}{c}0.016 \\
(0.122)\end{array}$ \\
\hline $\log ($ Average wage $)$ & $\begin{array}{l}0.981^{* *} \\
(0.382)\end{array}$ & $\begin{array}{l}0.992^{* * *} \\
(0.383)\end{array}$ & $\begin{array}{l}0.310^{* *} \\
(0.128)\end{array}$ & $\begin{array}{l}0.308^{* *} \\
(0.133)\end{array}$ \\
\hline Year FEs & Yes & Yes & Yes & Yes \\
\hline Industry FEs & No & No & No & No \\
\hline Firm FEs & Yes & Yes & Yes & Yes \\
\hline Time Trends & No & Yes & No & Yes \\
\hline Observations & 44883 & 44883 & 46303 & 46303 \\
\hline Number of firms & 11132 & 11132 & 11425 & 11425 \\
\hline
\end{tabular}

Notes: PPML regressions of the ratio of a firm's revenues from domestic services and revenues from goods on industry tariffs, the log of firm productivity, and the log average wage. FEs indicate fixed effects in the model. Time trends are 2-digit UK SIC industry time trends. Data Source: ONS Annual Respondents Database (ARD) and International Trade in Services Inquiry (ITIS). Standard errors are clustered at the industry level and are in parentheses, where ${ }^{*} \mathrm{p}<0.10,{ }^{* *} \mathrm{p}<0.05,{ }^{* * *} \mathrm{p}<0.01$.

Table 12: Tariffs and Industry Characteristics

\begin{tabular}{|c|c|c|c|c|}
\hline \multirow[b]{2}{*}{ Variables } & \multicolumn{4}{|c|}{$\Delta$ Goods Import Tariffs } \\
\hline & (1) & $(2)$ & (3) & (4) \\
\hline$\Delta$ Average wage & $\begin{array}{c}-0.021 \\
(0.024)\end{array}$ & & & $\begin{array}{r}-0.017 \\
(0.024)\end{array}$ \\
\hline$\Delta$ Employment & & $\begin{array}{c}0.000 \\
(0.004)\end{array}$ & & $\begin{array}{c}0.008 \\
(0.007)\end{array}$ \\
\hline$\Delta$ Sales & & & $\begin{array}{r}-0.004 \\
(0.004)\end{array}$ & $\begin{array}{r}-0.009 \\
(0.006)\end{array}$ \\
\hline Constant & $\begin{array}{c}-0.533^{* * *} \\
(0.021)\end{array}$ & $\begin{array}{c}-0.520^{* * *} \\
(0.015)\end{array}$ & $\begin{array}{c}-0.518^{* * *} \\
(0.015)\end{array}$ & $\begin{array}{c}-0.526^{* * *} \\
(0.021)\end{array}$ \\
\hline Observations & 225 & 225 & 225 & 225 \\
\hline R-squared & 0.003 & 0.000 & 0.004 & 0.014 \\
\hline
\end{tabular}


Table 13: Firm Attrition and Tariffs

\begin{tabular}{lccc}
\hline & \multicolumn{3}{c}{ Exiter $=1$} \\
\cline { 2 - 4 } Variables & $(1)$ & $(2)$ & $(3)$ \\
\hline$\Delta$ Goods import tariffs & -0.039 & -0.045 & -0.048 \\
& -0.002 & $(0.036)$ & $(0.039)$ \\
Initial Service/Goods revenue & -0.015 & -0.030 \\
& $-0.005)$ & $(0.019)$ & $(0.030)$ \\
$\Delta$ Goods import tariff * Initial Service/Goods revenue & -0.013 & -0.019 \\
& $(0.026)$ & $(0.026)$ & $(0.029)$ \\
$\Delta$ Services import barriers & & $-0.193^{* *}$ & $-0.219^{* *}$ \\
& & $(0.086)$ & $(0.090)$ \\
$\Delta$ Services import barriers * Initial Service/Goods revenue & & -0.131 & -0.224 \\
& & & $(0.203)$ \\
$\Delta$ Goods export tariffs & & & 0.016 \\
& & & $(0.045)$ \\
$\Delta$ Goods export tariff * Initial Service/Goods revenue & & & $(0.028$ \\
& & & -0.002 \\
$\Delta$ Services export barriers & & & $0.001)$ \\
$\Delta$ Services export barriers * Initial Service/Goods revenue & & & $(0.003)$ \\
\hline Observations & 40732 & 40317 & 38827 \\
R-squared & 0.000 & 0.001 & 0.002 \\
\hline
\end{tabular}

Notes: Dependent variable (Exiter $=1$ ) is 1 if the firm exits the BSD (employment falls to zero) at some point during the period 1997 to 2007. The firm can enter at any point. Independent change variables (denoted $\Delta)$ are average annual changes over the lifetime of the firm (could be fewer than 11 years). Standard errors are clustered at the industry level and are in parentheses, where ${ }^{*} \mathrm{p}<0.10,{ }^{* *} \mathrm{p}<0.05,{ }^{* * *} \mathrm{p}<0.01$. 
Table 14: Exports of Headquarters Services and Intermediate Inputs

\begin{tabular}{lccccc}
\hline & \multicolumn{2}{c}{ Exported HQ Services } & \multicolumn{2}{c}{$\begin{array}{c}\text { Ratio of Service/ } \\
\text { Goods Revenue }\end{array}$} \\
\cline { 2 - 3 } \cline { 5 - 6 } Variables & $(1)$ & $(2)$ & & $(3)$ & $(4)$ \\
\hline Goods import tariffs & 0.065 & 0.075 & & $-0.211^{* * *}$ & $-0.221^{* * *}$ \\
& $(0.048)$ & $(0.047)$ & & $(0.064)$ & $(0.066)$ \\
Goods input tariffs & & & -0.107 & -0.152 \\
& & & $(0.153)$ & $(0.164)$ \\
Goods export tariffs & 0.174 & $0.269^{*}$ & & -0.053 & -0.053 \\
& $(0.171)$ & $(0.151)$ & & $(0.047)$ & $(0.047)$ \\
Services export barriers & -2.319 & -2.351 & & 0.0382 & 0.123 \\
& $(3.248)$ & $(3.502)$ & & $(0.087)$ & $(0.094)$ \\
Services import barriers & -0.718 & -0.454 & & -0.187 & -0.845 \\
& $(1.070)$ & $(1.007)$ & & $(1.028)$ & $(1.244)$ \\
Log(Labor productivity) & $-0.437^{* * *}$ & $-0.412^{* *}$ & & -0.277 & -0.274 \\
& $(0.156)$ & $(0.161)$ & & $(0.227)$ & $(0.226)$ \\
Log(Average wage) & $-0.806^{* *}$ & $-0.791^{* *}$ & & $0.959^{* * *}$ & $0.956^{* * *}$ \\
& $(0.346)$ & $(0.346)$ & $(0.359)$ & $(0.359)$ \\
\hline Year FEs & Yes & Yes & Yes & Yes \\
Industry FEs & No & No & No & No \\
Firm FEs & Yes & Yes & Yes & Yes \\
Time Trends & No & Yes & No & Yes \\
\hline Observations & 2020 & 2020 & 54905 & 54905 \\
Number of Firms & 339 & 339 & 14284 & 14284 \\
\hline
\end{tabular}

Notes: PPML regressions of the ratio of a firm's revenues from services and revenues from goods on industry tariffs, the log of firm productivity, and the log average wage. The sharp drop in the number of observations is due to the fact that firms that never export headquarter services are dropped from the sample as they do not contribute to the fixed-effect Poisson likelihood function (also see footnote 33). FEs indicate fixed effects in the model. Time trends are 2-digit UK SIC industry time trends. Data Source: ONS Annual Respondents Database (ARD) and International Trade in Services Inquiry (ITIS). Standard errors are clustered at the industry level and are in parentheses, where ${ }^{*} \mathrm{p}<0.10,{ }^{* *} \mathrm{p}<0.05,{ }^{* * *} \mathrm{p}<0.01$. 
Table 15: Interaction Regressions and Beginning-of-Period Firm-Level Covariates

\begin{tabular}{|c|c|c|c|c|c|}
\hline \multirow[b]{2}{*}{ Variables } & \multicolumn{5}{|c|}{ Ratio of Service/Goods Revenue } \\
\hline & $(1)$ & $(2)$ & $(3)$ & $(4)$ & $(5)$ \\
\hline Goods import tariffs & $\begin{array}{c}-0.139 \\
(0.244)\end{array}$ & $\begin{array}{r}-0.198 \\
(0.307)\end{array}$ & $\begin{array}{r}-0.178 \\
(0.317)\end{array}$ & $\begin{array}{r}-0.184 \\
(0.341)\end{array}$ & $\begin{array}{c}-0.148 \\
(0.348)\end{array}$ \\
\hline Goods export tariffs & $\begin{array}{r}-0.080 \\
(0.059)\end{array}$ & $\begin{array}{r}-0.082 \\
(0.059)\end{array}$ & $\begin{array}{c}-0.081 \\
(0.059)\end{array}$ & $\begin{array}{r}-0.081 \\
(0.058)\end{array}$ & $\begin{array}{r}-0.077 \\
(0.059)\end{array}$ \\
\hline Services export barriers & $\begin{array}{c}0.129 \\
(0.156)\end{array}$ & $\begin{array}{c}0.128 \\
(0.157)\end{array}$ & $\begin{array}{c}0.128 \\
(0.156)\end{array}$ & $\begin{array}{c}0.129 \\
(0.157)\end{array}$ & $\begin{array}{c}0.141 \\
(0.157)\end{array}$ \\
\hline Services import barriers & $\begin{array}{c}1.242 \\
(0.792)\end{array}$ & $\begin{array}{c}1.253 \\
(0.795)\end{array}$ & $\begin{array}{c}1.240 \\
(0.792)\end{array}$ & $\begin{array}{c}1.228 \\
(0.764)\end{array}$ & $\begin{array}{c}0.963 \\
(0.744)\end{array}$ \\
\hline Goods import tariff * Initial R\&D & $\begin{array}{r}-0.110^{*} \\
(0.057)\end{array}$ & $\begin{array}{c}-0.114^{* *} \\
(0.056)\end{array}$ & $\begin{array}{r}-0.111^{*} \\
(0.058)\end{array}$ & $\begin{array}{r}-0.112^{*} \\
(0.060)\end{array}$ & $\begin{array}{r}-0.102^{*} \\
(0.058)\end{array}$ \\
\hline Goods import tariff $*$ Initial Capital investment & $\begin{array}{c}0.072 \\
(0.053)\end{array}$ & $\begin{array}{c}0.074 \\
(0.051)\end{array}$ & $\begin{array}{c}0.072 \\
(0.052)\end{array}$ & $\begin{array}{c}0.073 \\
(0.052)\end{array}$ & $\begin{array}{c}0.066 \\
(0.051)\end{array}$ \\
\hline Goods import tariff $* \log ($ Initial Labor productivity) & $\begin{array}{c}0.039 \\
(0.035)\end{array}$ & & $\begin{array}{c}0.028 \\
(0.055)\end{array}$ & $\begin{array}{c}0.027 \\
(0.056)\end{array}$ & $\begin{array}{c}0.020 \\
(0.053)\end{array}$ \\
\hline Goods import tariff $* \log ($ Initial Average wage) & & $\begin{array}{c}0.063 \\
(0.064)\end{array}$ & $\begin{array}{c}0.025 \\
(0.110)\end{array}$ & $\begin{array}{c}0.028 \\
(0.117)\end{array}$ & $\begin{array}{c}0.027 \\
(0.115)\end{array}$ \\
\hline Goods import tariff $*$ Initial Service revenue & & & & $\begin{array}{r}-0.010 \\
(0.081)\end{array}$ & $\begin{array}{r}-0.009 \\
(0.079)\end{array}$ \\
\hline $\log$ (Average wage) & $\begin{array}{c}0.311 \\
(0.394)\end{array}$ & $\begin{array}{c}0.297 \\
(0.386)\end{array}$ & $\begin{array}{c}0.305 \\
(0.392)\end{array}$ & $\begin{array}{c}0.303 \\
(0.387)\end{array}$ & $\begin{array}{c}0.293 \\
(0.384)\end{array}$ \\
\hline $\log$ (Labor productivity) & $\begin{array}{l}0.578^{* * *} \\
(0.171)\end{array}$ & $\begin{array}{l}0.585^{* * *} \\
(0.172)\end{array}$ & $\begin{array}{l}0.581^{* * *} \\
(0.176)\end{array}$ & $\begin{array}{l}0.580^{* * *} \\
(0.172)\end{array}$ & $\begin{array}{l}0.579^{* * *} \\
(0.172)\end{array}$ \\
\hline Year FEs & Yes & Yes & Yes & Yes & Yes \\
\hline Industry FEs & No & No & No & No & No \\
\hline Firm FEs & Yes & Yes & Yes & Yes & Yes \\
\hline Time Trends & No & No & No & No & Yes \\
\hline Observations & 7151 & 7151 & 7151 & 7151 & 7151 \\
\hline Number of Firms & 1322 & 1322 & 1322 & 1322 & 1322 \\
\hline
\end{tabular}

Notes: PPML regressions of the ratio of a firm's revenues from services and revenues from goods on industry tariffs, the log of firm productivity, and the log average wage. Time trends are 2-digit UK SIC industry time trends. Data Source: ONS Annual Respondents Database (ARD) and International Trade in Services Inquiry (ITIS). Standard errors are clustered at the industry level and are in parentheses, where ${ }^{*} \mathrm{p}<0.10,{ }^{* *} \mathrm{p}<0.05, * * * \mathrm{p}<0.01$. 